\title{
Biodigestion of Plant Material Can Improve Nitrogen Use Efficiency in a Red Beet Crop Sequence
}

\author{
Anita Gunnarsson ${ }^{1}$ \\ Department of Horticulture, Swedish University of Agricultural Sciences, \\ Box 103, Alnarp, Scania 230 53, Sweden
}

Börje Lindén

Department of Soil and Environment, Swedish University of Agricultural Sciences, P.O. 234, Gråbrödragatan 19, 53223 Skara, Sweden

Ulla Gertsson

Faculty of Health and Society, Malmö University, 20506 Malmö, Sweden

Additional index words. anaerobic digestion, digestate, barley, Beta vulgaris var. conditiva Alef., effluent, green manure, mixed ley

Abstract. Nitrogen (N) tied up in or lost from decomposing biomass decreases the residual $\mathrm{N}$ effects of green manure and of other crop residues. During anaerobic degradation in a biogas digestor (biodigestion), $\mathrm{N}$ mineralization takes place under conditions in which losses can be kept to a minimum. Therefore, biodigestion of green manure biomass and beet foliage was tested to generate readily available $\mathrm{N}$ and compared with a direct green manure fertilization system. The effluent was applied as fertilizer in field experiments on a sandy soil as a tool for improving $\mathrm{N}$ supply for an organic farming system. Data from the field experiments were used for simulating the amount of net inorganic $N$ equivalents (inorganic $\mathrm{N}$ equivalents from effluent plus inorganic $\mathrm{N}$ equivalents from pre-crops) in three crop sequences: A) green manure ley, red beets, winter rye; B) harvested ley, red beets, winter rye; and $C$ ) harvested ley, spring barley, red beets in which (B) and (C) represented biogas nutrient management systems and $(A)$ a green manure system. When all available effluent from biogas production from 1 ha of grass-clover ley with two or three harvests (2H-ley or $3 \mathrm{H}$-ley) and one hectare of beet foliage was used as a fertilizer for red beets (Beta vulgaris var. conditiva Alef) after barley (Hordeum vulgare L.), the

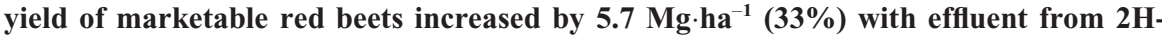
ley and beet foliage and $9.1 \mathrm{Mg} \cdot \mathrm{ha}^{-1}(53 \%)$ with effluent from $3 \mathrm{H}$-ley and beet foliage compared with red beets grown without effluent fertilization after a green manure ley. When total dry matter production was taken into account, the advantage for the BG systems with $2 \mathrm{H}$ - and $3 \mathrm{H}$-ley was $15 \%$ and $28 \%$, respectively. The nitrate concentration in the red beets was not higher with effluent supplied at this level than with green manure as the only $N$ source. The simulated amount of net inorganic $N$ equivalents was $128 \mathrm{~kg} \mathrm{~N}$ for the whole of crop sequence $(C)$ with 1 ha of each crop and where effluent supply to red beets was based on digested biomass in ley and beet tops. The corresponding amount of net inorganic $\mathbf{N}$ equivalents for the green manure crop sequence (A), in which no effluent was supplied, was $73 \mathrm{~kg} \mathrm{~N}$. Unused soil mineral $N(0-$ to $90-\mathrm{cm}$ depth) at red beet harvest indicated that the risk of leaching in BG systems was lower than in GrM systems $(88,76$, and $61 \mathrm{~kg} \mathrm{~N} \mathrm{~N}_{\min } /$ ha left after unmanured beets after Gr-M-ley, low manured beets after 3H-ley and high manured beets after barley, respectively). Effluent fertilization of red beets directly after $2 \mathrm{H}$ - and $3 \mathrm{H}$-ley gave unexpectedly low yield responses compared with red beets after barley. The reasons may be the result of nutritional imbalance of other nutrients than $\mathbf{N}$ or may be plant pathological in nature. The conclusion is that a nutrient management system with biodigestion can increase net inorganic $\mathrm{N}$ equivalents and reduce risk for $\mathrm{N}$ leaching, but inappropriate use of the effluent, i.e., at an unsuitable point in the crop rotation, may negate the benefits.

Received for publication 13 July 2010. Accepted for publication 4 Feb. 2011.

This research was funded by SLU EkoForsk and SJV

We thank Irene Bohn and Lovisa Björnsson, Department of Biotechnology, Lund University, for assistance regarding the pilot scale biogas production.

This article is intended to be a portion of a $\mathrm{PhD}$ Thesis by A. Gunnarsson.

${ }^{1}$ To whom reprint requests should be addressed; e-mail anita.gunnarsson@slu.se.
Green manure (GrM) crops are important for improving or maintaining soil fertility in organic farming. Nitrogen fixing species are essential for organic farming systems intended to be self-sufficient with respect to N. A typical practice in organic farms without livestock in southern Sweden is cultivation of a GrM crop consisting of a mixture of white clover, red clover, and grass undersown in a cereal crop in the year preceding the GrM year. The ley biomass is normally cut two or three times in the summer of the GrM year and incorporated into the soil the next spring. When growing an $\mathrm{N}$-demanding crop such as red beets for food processing, a certified organic fertilizer containing some inorganic $\mathrm{N}$ is often applied immediately before planting the crop. Thus, the farms are then not $\mathrm{N}$ self-sufficient

Leaving the plant material of a cut green manure crop on the field involves a risk of $\mathrm{N}$ losses (Janzen and McGinn, 1991; Torstensson et al., 2006). It has been suggested that the $\mathrm{N}$ use efficiency of GrM can be improved by using the biomass as raw material in an anaerobic biodigestor for biogas production and returning the residues as fertilizer instead of leaving the ley biomass in the field for its direct green manure effect (Svensson, 2005). Whether a biogas nutrient management system (BG system) with its $\mathrm{N}$ supply originating from biodigested plant material has a better first-year $\mathrm{N}$ fertilization effect than a green manure nutrient management system with its $\mathrm{N}$ supply originating from grassclover green manure ley (GrM system) would depend on many factors. We reasoned that important factors would be 1) the effect of removing, instead of leaving, the cut grassclover biomass on growth, $\mathrm{N}$ uptake, $\mathrm{N}$ fixation, and chemical composition, especially $\mathrm{C}: \mathrm{N}$ ratio of the different ley species; 2) the amount of $\mathrm{N}$ and the chemical composition of other crop residues such as red beet foliage that can be used in biogas production; 3 ) the net mineralization of $\mathrm{N}$ from crop residues; 4) the efficiency of microorganisms in the biodigestor to degrade carbon and thereby simultaneously mineralize organic plant $\mathrm{N}$ to ammonium $\left.\mathrm{N}\left(\mathrm{NH}_{4}-\mathrm{N}\right) ; 5\right)$ the ability of the crop to use effluent $\mathrm{N}$; and 6) the ability of the crop to use $\mathrm{N}$ mineralized from crop residues of green manure, harvested grass-clover ley, and from other crop residues. The total impact of these parameters would determine the difference between a GrM system and a BG system. Some of the parameters in factor (1), (3) and (6) have already been identified using data from the present investigation as reported by Gunnarsson et al. (2008): (1) a harvested grass-clover ley produced a smaller amount of total aboveground biomass and $\mathrm{N}$ than a cut green manure ley, but the clover proportion was unaffected by the treatment; (3) and (6): both apparent net $\mathrm{N}$ mineralization and $\mathrm{N}$ uptake by crop was less in a red beet crop after harvested ley than after GrM-ley (Gunnarsson et al., 2008). Loges et al. (2000) also found that $\mathrm{N}_{2}$ fixation by leguminous plants can be increased if the ley is harvested instead of being used as a green manure. For a silty loam with $25 \%$ to $30 \%$ clay, Stinner et al. (2008) showed an increase both in total $\mathrm{N}$ uptake and estimated biological $\mathrm{N}$ fixation of a harvested grass-clover ley compared with a GrM-ley. From the same experiments as those reported by Stinner et al. (2008), Möller (2009) reported an impaired $\mathrm{N}$ balance (in this case a larger surplus calculated as $\mathrm{N}$ with $\mathrm{N}_{2}$ fixation minus output in sold products) in a $\mathrm{BG}$ system compared with a GrM system. The humus balance was kept positive although the 
surplus was lower in the BG system than in the GrM system. Soil mineral $\mathrm{N}$ in fall was lower in the BG system than in the GrM system (Möller and Stinner, 2009). We only found two other works about nutrient system effects of biogas digestion of plants, both on soils with rather high clay contents (Båth and Elfstrand, 2008; Ross et al., 1989).

In the present investigation, effluent from biogas production (biodigestor effluent) was used as a fertilizer in the production of red beets. The impact on red beet yield and quality and the net inorganic $\mathrm{N}$ equivalents (inorganic $\mathrm{N}$ equivalents from effluent plus inorganic $\mathrm{N}$ equivalents from previous crops) were studied as part of a crop rotation with and without biodigestion of crop residues on a sandy soil in southern Sweden. The aim of this study was to test the hypothesis that harvesting the ley and beet foliage for biodigestion and returning the biodigestor effluent as fertilizer would improve the $\mathrm{N}$ supply to beets and cereals in the crop sequence and increase the marketable red beet yield without increasing the content of unused plantavailable $\mathrm{N}$ in soil after red beet harvest and without jeopardizing red beet quality in terms of excessive nitrate $\left(\mathrm{NO}_{3}{ }^{-}\right)$concentration.

\section{Materials and Methods}

\section{Field trials}

A 2-year field trial was carried out in 20022003 and repeated in 2003-2004 in an organic cultivation system on the Lilla Böslid experimental farm (lat. $56^{\circ} 60^{\prime} \mathrm{N}$, long. $12^{\circ} 54^{\prime} \mathrm{E}$ ) in southern Sweden. The field experiments included a pre-crop year with either spring barley (Hordeum vulgare L. cultivar Baronesse) with undersown perennial ryegrass (Lolium perenne) or a first-year ley crop harvested twice (2H-ley), three times (3H-ley), or not harvested but grown for its green manure effect (GrMley) and a subsequent crop of red beet (Beta vulgaris var. conditiva Alef. cultivar Boro) with different fertilization regimes. The red beet crop was used as a model crop because it has a relatively high $\mathrm{N}$ requirement.
Pre-crop year (2002 and 2003). In 2001, the ley of the first experiment was undersown in unfertilized spring barley after weed harrowing in the two- to three-leaf stage of the barley. In 2002, the ley of the second experiment was sown in the beginning of July without barley after a short fallow period with a mechanical treatment to control couch-grass (Agropyron repens). The seed mixture (22 $\mathrm{kg} \cdot \mathrm{ha}^{-1}$ ) consisted of $20 \%$ red clover (Trifolium pratense L.), 10\% white clover (Trifolium repens L.), and $70 \%$ perennial ryegrass (Lolium perenne L.) based on weight. In the pre-crop year, the biomass in $2 \mathrm{H}$ - and $3 \mathrm{H}$-leys was harvested with a flail forage harvester in the beginning of June (Week 23), late July (Week 30), and, for the 3H-ley, also in the beginning of October (Week 41) (same weeks in 2002 and 2003). The biomass in the GrMley and the 2H-ley was left untouched from late July until soil tillage in the spring, including ploughing. Apart from the third harvest, the $2 \mathrm{H}$-ley and the $3 \mathrm{H}-\mathrm{ley}$ underwent exactly the same treatment. The GrM-ley was cut with a Votex Maxxum 4/340 (Votex b.v., The Netherlands) on the same dates in June and July as the 2H-ley and $3 \mathrm{H}$-leys. The machine chopped the plant material into small pieces and distributed it evenly on the soil surface. The mean ratio of clover in ley biomass dry matter (DM) in the pre-crop years was $60 \%$, of which $80 \%$ to $90 \%$ was white clover (further details presented by Gunnarsson et al., 2008). Grain and straw of spring barley were harvested at maturity. No fertilizer was supplied in the pre-crop year or in the year preceding the pre-crop year. Soil tillage after barley was performed at the same time as after the ley pre-crops.

Red beet year (2003 and 2004). The red beet crop was fertilized with effluent from biodigested plant material according to four differently chosen mineral $\mathrm{N}$ target values (denominated $1,2,3$, or $4 \mathrm{~N}-\mathrm{t}$ ) or without addition of effluent ( $0 \mathrm{EF}$ ) but with Besal (AB Hansson \& Möhring) and Kali vinasse (Table 1). The intention with Treatments IV and VIII to XI (Table 1), with increasing $\mathrm{N}$ supply to red beets with a spring barley pre-crop, was to determine an $\mathrm{N}$ response equation for the actual field and year. The target values for soil mineral $\mathrm{N}\left(\mathrm{NH}_{4}-\mathrm{N}+\mathrm{NO}_{3}-\mathrm{N}=\mathrm{N}_{\min }\right)$ plus effluent $\mathrm{NH}_{4}-\mathrm{N}$ were estimated for three application times using the growth and fertilization model N_ABLE (Greenwood, 2001). Target values were chosen so that a red beet yield of 15 to $20 \mathrm{Mg} \cdot \mathrm{ha}^{-1}$ could be expected in the treatments with the lowest effluent supply and with barley as a pre-crop (Treatment VIII and IX) and $50 \mathrm{Mg} \cdot \mathrm{ha}^{-1}$ at the highest level (Treatment XI). The 50-Mg ha $^{-1}$ level was chosen according to earlier experience of the potential yield. The target values after leys were the same as for Treatment VIII (with the $1 \mathrm{~N}-\mathrm{t}$ fertilizing regime) in 2003 and as for Treatment IX (with the $2 \mathrm{~N}$-t fertilizing regime) in 2004 and are therefore denominated Low N-t. For calculating the need of effluent $\mathrm{NH}_{4}-\mathrm{N}$ supply at the first application (before drilling), $\mathrm{N}_{\min }$ in the 0 - to $30-\mathrm{cm}$ layer was used, whereas $\mathrm{N}_{\min }$ in the 0 - to $60-\mathrm{cm}$ layer was considered for the second and third applications. The effluent was applied before drilling with a band spreader and incorporated into the soil within $1 \mathrm{~h}$ of spreading by harrowing and by interrow cultivating after the applications in June and July. Additional effluent application to reach the $\mathrm{N}$ target values was only needed in July in the three highest regimes after barley in 2003 and in the two highest $\mathrm{N}$ target regimes in 2004. The highest effluent rate added in a single application was $73 \mathrm{~m}^{3} \cdot \mathrm{ha}^{-1}$. This rate percolated quickly into the sandy soil and did not cause problems with surface runoff. Nutrient content in Kali vinasse, used in treatments without effluent application, was $(\%)$ : 33 potassium $(\mathrm{K}), 1$ organic $\mathrm{N}$ $\left(\mathrm{N}_{\text {org }}\right), 0 \mathrm{NH}_{4}-\mathrm{N}, 0.002$ phosphorus $(\mathrm{P}), 0.7$ calcium $(\mathrm{Ca}), 0.6$ magnesium $(\mathrm{Mg})$, and 20 sulfur (S). Besal (crushed rock salt) contained $38 \%$ sodium $(\mathrm{Na})$ as sodium chloride $(\mathrm{NaCl})$. Because the $\mathrm{P}$ balance in the preceding crop rotations was positive and soil $\mathrm{P}$ status was good, no extra $\mathrm{P}$ was added.

Table 1. Pre-crops and nutrient supply in the different fertilization regimes in the field trials during the second experimental year (red beet year). ${ }^{z}$

\begin{tabular}{|c|c|c|c|c|c|c|}
\hline \multirow[b]{3}{*}{ Treatment } & \multirow{3}{*}{$\begin{array}{l}\text { Pre-crop (during the } \\
\text { first experimental yr) }\end{array}$} & \multicolumn{4}{|c|}{ Fertilization regime during the red beet yr } & \multirow{3}{*}{$\frac{\text { Abbreviation }}{\begin{array}{c}\text { Pre-crop/fertilization } \\
\text { regime }\end{array}}$} \\
\hline & & \multicolumn{4}{|c|}{ Nutrient supply with fertilizers $\left(\mathrm{kg} \cdot \mathrm{ha}^{-1}\right)$} & \\
\hline & & $\mathrm{Na}$ & $\mathrm{K}$ & $\mathrm{NH}_{4}-\mathrm{N}$ & Total N & \\
\hline \multicolumn{7}{|c|}{ Fertilization: Kali vinasse and Besal } \\
\hline I & Ley, used as green manure (control) & 40 & 100 & 0 & 2 & GrM-ley/0 EF \\
\hline II & Ley, harvested 2 times & 40 & 200 & 0 & 6 & 2H-ley/0 EF \\
\hline III & Ley, harvested 3 times & 40 & 200 & 0 & 6 & 3H-ley/0 EF \\
\hline IV & Spring barley with undersown ryegrass & 40 & 150 & 0 & 3 & Barley/0 EF \\
\hline \multicolumn{7}{|c|}{ Fertilization with effluent from biogas production using crop materials } \\
\hline $\mathrm{V}$ & Ley, used as green manure & 20 & 84 & 26 & 61 & GrM-ley/Low N-t \\
\hline VI & Ley, harvested 2 times & 41 & 174 & 54 & 127 & 2H-ley/Low N-t \\
\hline VII & Ley, harvested 3 times & 50 & 210 & 65 & 153 & 3H-ley/Low N-t \\
\hline VIII & Spring barley with undersown ryegrass & 33 & 139 & 43 & 101 & Barley/1 N-t \\
\hline IX & Spring barley with undersown ryegrass & 81 & 339 & 105 & 250 & Barley/2 N-t \\
\hline $\mathrm{X}$ & Spring barley with undersown ryegrass & 120 & 504 & 156 & 364 & Barley/3 N-t \\
\hline XI & Spring barley with undersown ryegrass & 155 & 653 & 202 & 473 & Barley/4 N-t \\
\hline
\end{tabular}

${ }^{\mathrm{z}}$ Mean for 2003 and 2004. Ley $=$ grass-clover.

$\mathrm{y}_{0} \mathrm{EF}=$ without addition of effluent; $1,2,3$, and $4 \mathrm{~N}-\mathrm{t}=$ fertilization to red beets determined according to increasing $\mathrm{N}$ targets for soil mineral $\mathrm{N}$ plus effluent $\mathrm{NH}_{4}$ $\mathrm{N}$ in which $1 \mathrm{~N}-\mathrm{t}$ is the treatment with the lowest $\mathrm{N}$ targets and $4 \mathrm{~N}-\mathrm{t}$ with the highest. Low N-t is used for grass-clover leys in which the $\mathrm{N}$ target was the same as in Treatment VIII in 2003 and as in Treatment IX in 2004.

$\mathrm{Na}=$ sodium; $\mathrm{K}=$ potassium; $\mathrm{N}=$ nitrogen. 
The red beet seed was planted at 40 seeds per meter with rows spaced of $50 \mathrm{~cm}$. This allowed a final plant density of $\approx 550$ thousand plants per hectare, which is normally sufficient for maximum root yield. In 2003, May was wetter and the summer warmer than in 2004 (Table 2), which resulted in later drilling and earlier harvesting in 2003 than in 2004. Average dates in 2003 and 2004 for the main cultivation activities during the red beet years were: 8 and 23 Apr., respectively, for incorporation of the ley with a heavy disc harrow ( $\approx 10$-cm soil depth), 19 May and 29 Apr. for ploughing ( $\approx 20$-cm depth), 27 and 12 May for fertilization before drilling (effluent or Kali vinasse and Besal; see Table 1), 31 and 18 May for drilling, 3 July and 21 June for the second and 31 and 28 July for the third effluent fertilizations (if needed according to target values), and 3 and 21 Sept. for harvesting.

Experimental design, soil, and weather. The experiments were performed using a randomized complete block design with four replicates. Plot size was $14 \mathrm{~m} \times 6 \mathrm{~m}$ with $4-\mathrm{m}$ distance between plots in the longitudinal direction. The experiments in 2002-2003 and 2003-2004 were located on adjoining fields with the same crop rotation. The topsoils, according to samples from the $30-\mathrm{cm}$ soil layer, were sandy with on average $89 \%$ sand, $7 \%$ silt, $4 \%$ clay, $1.6 \%$ carbon $(\mathrm{C}), \mathrm{C} / \mathrm{N}=9$, and $\mathrm{pH}\left(\mathrm{H}_{2} \mathrm{O}\right)=6.4$. In the subsoil $(30$ to $90 \mathrm{~cm})$, the clay content was on average less than $2 \%$ and total $\mathrm{C}$ was $0.4 \%$. Plant-available $\mathrm{P}, \mathrm{K}$, $\mathrm{Mg}$, and $\mathrm{Ca}$ in the topsoil with barley precrops was $12,7,9$, and $76 \mathrm{mg} / 100 \mathrm{~g}$ air-dried soil, respectively, according to analyses with the ammonium acetate lactate method (Egnér et al., 1960). Water-soluble boron was 0.3 $\mathrm{mg} \cdot \mathrm{kg}^{-1}$. The fields had been under organic production since 1995 with a 6-year crop rotation comprising spring barley with undersown grass-clover, green manure ley followed by potatoes or red beets; thus, potatoes or red beets were grown every sixth year. During the period with organic farming, farmyard manure had been applied twice in the crop rotation. For more details about plant-available nutrients see, Gunnarsson et al. (2008).

Temperature, precipitation, and irrigation are shown in Table 2. In July 2003 and in July and Aug. 2004, the precipitation was much above the 30 -year mean. According to Brewster and Sutherland (1993), the lowest temperature for red beet growth is $5.6{ }^{\circ} \mathrm{C}$. With that as the base temperature, above which temperature is counted, the accumulated number of day-degrees from sowing to

Table 2. Weather data for the experimental period and 30-year mean values (1961-1990, for Halmstad $10 \mathrm{~km}$ north of the experimental site; Alexandersson and Eggertsson Karlström, 2001). ${ }^{\mathrm{z}}$

\begin{tabular}{|c|c|c|c|c|c|c|c|c|}
\hline \multirow[b]{2}{*}{ Period } & \multicolumn{4}{|c|}{ Avg temp $\left({ }^{\circ} \mathrm{C}\right)$} & \multicolumn{4}{|c|}{ Precipitation + irrigation (mm) } \\
\hline & 2002 & 2003 & 2004 & 30-yr mean & 2002 & 2003 & 2004 & 30-yr mean \\
\hline January to April & 4 & 1 & 2 & 1 & 210 & 152 & 184 & 170 \\
\hline May & 13 & 11 & 11 & 11 & 81 & 98 & $55+10$ & 42 \\
\hline June & 16 & 16 & 13 & 15 & 135 & 53 & 85 & 61 \\
\hline July & 18 & 18 & 15 & 16 & 104 & $121+14$ & 156 & 71 \\
\hline August & 20 & 17 & 18 & 16 & 82 & $84+35$ & $121+20$ & 86 \\
\hline $\begin{array}{l}\text { September (until } \\
\text { harvest) }\end{array}$ & - & 10 & 14 & - & 一 & 0 & 69 & - \\
\hline
\end{tabular}

Zrrigation was only used on the red beet crop.

harvest was 1077 in 2003 (96 d) and 1175 in 2004 (127 d).

\section{Biodigestion and effluent production}

The biodigestion was performed with a one-step process at $35{ }^{\circ} \mathrm{C}$ in a batch-fed stirred $80-\mathrm{m}^{3}$ anaerobic biodigestor. The biodigestor tank was fed with beet leaves (approximately one-third of added DM) and grass-clover from a first-year ley. Because more plant material was needed, for feeding the $80-\mathrm{m}^{3}$ reactor, than could be produced in the experiment plots, plant material was obtained from organically grown crops from other fields and stored as silage before being fed into the biodigestor. On average, $\mathrm{N}$ concentration in the ley and beet foliage used for feeding the biodigestor was the same as in the plant material harvested in the field experiment. In the fall of 2002, when the biodigestor was started, it was inoculated with sludge from another anaerobic biodigestor using beet foliage. Volatile fatty acids (VFA) increase $\mathrm{N}$ immobilization in the effluent when added to soil (Kirchmann and Lundvall, 1993). In the final effluent, used as fertilizer, the VFA levels were below the detection limit $\left(0.01 \mathrm{~g} \cdot \mathrm{L}^{-1}\right)$ in both years, and $\mathrm{pH}$ averaged 7.4. Biogas production was stable with an estimated methane $\left(\mathrm{CH}_{4}\right)$ yield, measured at atmospheric pressure, of $0.21 \mathrm{~m}^{3} \cdot \mathrm{kg}^{-1}$ volatile solids (VS) in 2003 and $0.25 \mathrm{~m}^{3} \cdot \mathrm{kg}^{-1}$ VS in 2004. The stirring equipment was less efficient in the first year, which was probably the main reason for the lower methane production and also for a lower $\mathrm{NH}_{4}-\mathrm{N}$ :total $\mathrm{N}$ ratio: 0.38 $( \pm 0.06)$ in 2003 and $0.46( \pm 0.01)$ in $2004( \pm$ $\mathrm{SD} ; \mathrm{n}=3) . \mathrm{C}: \mathrm{N}_{\text {org }}$ ratio was $9( \pm 1)$ in 2003 and $11( \pm 1)$ in 2004 . As a mean for 2 years and three sampling times per year, the DM content in the effluent was $6 \%$. The nutrient concentrations in the effluent $\left(\mathrm{kg} \cdot \mathrm{Mg}^{-1}\right.$ fresh weight) were: $1.3 \mathrm{NH}_{4}-\mathrm{N}, 1.9 \mathrm{~N}_{\text {org }}$, (i.e., 3.2 total $\mathrm{N}$ ), $0.4 \mathrm{P}, 4.2 \mathrm{~K}, 1.0 \mathrm{Na}, 0.4 \mathrm{Mg}, 0.2 \mathrm{~S}, 0.141$ iron, 0.006 manganese, 0.005 zinc, 0.004 boron, and 0.001 copper. The chloride content was $1.5 \mathrm{~kg} \cdot \mathrm{Mg}^{-1}$ fresh weight. The density of the effluent was $1 \mathrm{~kg} \cdot \mathrm{L}^{-1}$.

\section{Sampling and analyses}

In the first experimental year, a flail forage harvester with a balance was used to measure yields of harvested ley from $21 \mathrm{~m}^{2}$ per plot. The material was analyzed for DM and Kjeldahl-N (Kjeltec Auto 1035 Analyser; Tecator AB, Höganäs, Sweden). The $\mathrm{N}$ analyses were performed on one sample per harvest, treatment, and block.

HortScience Vol. 46(5) May 2011
Mineral N in the 0 - to 30 - and 30 - to $60-\mathrm{cm}$ soil layers was determined on four occasions in the second experimental year: before drilling, in June (5 to $7 \mathrm{~d}$ before the second fertilization with effluent), in July (5 to $7 \mathrm{~d}$ before the third fertilization with effluent), and immediately after beet harvest. On the first and last sampling occasions, the $60-$ to $90-\mathrm{cm}$ soil layer was also sampled. Before drilling, $\mathrm{N}_{\text {min }}$ was determined by block and pre-crop history and on the other sampling occasions plotwise. Each soil sample consisted of 10 soil cores mixed together. Extraction was made in $2 \mathrm{M}$ $\mathrm{KCl}$ (w:v 1:3; $3 \mathrm{~h}$ shaking at room temperature) and the extracts were analyzed for ammonium $\mathrm{N}$ and nitrate $\mathrm{N}$ by flow injection analysis. Sample handling followed the international standard ISO 14 256. The $\mathrm{N}_{\min }$ was used as the basis for $\mathrm{N}$ target fertilization (more data presented in Gunnarsson et al., 2008). Before drilling the red beet crop, separate samples from the $0-$ to $25-\mathrm{cm}$ soil layer from each treatment, thus with each precrop, were also taken and then analyzed for plant-available $\mathrm{P}, \mathrm{K}, \mathrm{Mg}$, and $\mathrm{Ca}$ according to the ammonium acetate lactate method (Egnér et al., 1960). Plant-available K was used to decide the application rate of Kali vinasse.

Red beets were harvested by hand within four 5-m red beet row sections per plot. Harvested beets were shredded in a food processor, and beets and leaves were dried at $70{ }^{\circ} \mathrm{C}$ and analyzed for total N content according to Dumas on a LECO FP-428 (LECO Corporation, St. Joseph, MI). All yield and nutrient determinations were performed on beets from rows that were unaffected by wheel traffic during drilling, effluent spreading, or other machine operations.

Beet nitrate concentrations were determined by high-performance liquid chromatography. For this, the fresh biomass of unpeeled red beets from the 40- to $60-\mathrm{mm}$ diameter (Ø) fraction was used with the root tip and red beet top removed. This determination was made on red beets from all treatments with barley as the pre-crop (IV, VIII to XI) and from the treatments with GrM-ley and 3H-ley as a pre-crop without the addition of effluent to the red beets (I and III)

Samples for determination of volatile fatty acids and lactate in the effluent from the biodigestor were analyzed as described by Björnsson et al. (2000). Nutrient content was measured before each application, i.e., three times a year. Total $\mathrm{N}$ and $\mathrm{NH}_{4}-\mathrm{N}$ in the effluent were determined on fresh subsamples using the Kjeldahl technique (Kjeltec Auto 1035 Analyzer; Tecator AB). Dry matter was determined after drying at $105{ }^{\circ} \mathrm{C}$. Micronutrients and $\mathrm{P}, \mathrm{K}, \mathrm{Ca}, \mathrm{Mg}, \mathrm{Na}$, and $\mathrm{S}$ were determined on dried subsamples with inductively coupled plasma-optical emission spectroscopy (ICP-OES) after digestion according to NMKL (1998). Water-soluble chlorine was determined with ICP-OES. Carbon was determined according to Dumas on a LECO FP-428 (LECO Corporation, St. Joseph, MI). Carbon determination was made after drying the samples at $50{ }^{\circ} \mathrm{C}$ until the residual water content reached $\approx 10 \%$. Nitrate was not 
determined in the effluent because it was kept under anaerobic conditions until the application day.

\section{Simulated crop sequences and calculation of nitrogen supply and efficiency in the systems}

In a BG nutrient management system, compared with a GrM system, the pre-crop effect of ley and red beets is reduced as a result of removal of plant materials from the fields (Gunnarsson et al., 2008), but increased flexibility in the system is gained as a result of the effluent (Möller et al., 2008a; Stinner et al., 2008). A fair judgment of system effects needs to take at least 3 years into account. Therefore, despite the 2-year field experiments, we simulated the following 3-year crop sequences for consideration of residual effects with the crops included in the field trials being marked in bold type:

GrM system, Sequence A: Year 1) GrM-ley; 2) red beets; 3) winter rye.

BG system, Sequence B: Year 1) harvested ley; 2) red beets; 3) winter rye.

BG system, Sequence C: Year 1) harvested ley; 2) spring barley; 3 ) red beets.

The aim was to simulate how both beets and cereals were supplied with $\mathrm{N}$ produced in the crop sequences as a result of pre-crop effects. The crop sequence simulation was made with the following prerequisites and assumptions:

1. The experiments did not include measurements in the year after the red beets. To account for the increased $\mathrm{N}$ fertilization effect of red beet foliage compared with cereals $\left(\mathrm{N}_{\mathrm{R} \text {-foliage }}\right)$, we estimated it for relevant climate and soil conditions (see further under Eq. 2 ). We assumed winter rye to be the most probable cereal after red beets because it can be drilled in September, is suitable for the sandy soil, and may benefit from mineralized $\mathrm{N}$ from red beet foliage and unused $\mathrm{N}_{\text {min }}$ after red beets. The winter rye was assumed to be unfertilized and to have the same residual effect as barley.

2. Crop sequence $\mathrm{C}$ was meant to illustrate the flexibility in choosing a crop sequence in an organic BG system with the opportunity to move $\mathrm{N}$ from the ley through the biodigestor to a crop not directly after ley. However, the experiments did not include any treatment with spring barley after harvested ley like in crop sequence $\mathrm{C}$. Therefore, we assumed that the increased $\mathrm{N}$ fertilization effect of ley compared with cereals $\left(\mathrm{N}_{\mathrm{R} \text {-ley }}\right)$ was the same for spring barley as for red beets. The barley was assumed to be unfertilized and followed by perennial ryegrass as an undersown catch crop ploughed under in spring.

For comparing the GrM and BG systems with respect to the crop Sequence A, B, and
$\mathrm{C}$, parameters characterizing $\mathrm{N}$ supply to crops and $\mathrm{N}$ efficiency are introduced subsequently.

When comparing different composted or anaerobically digested organic fertilizers with each other or with mineral fertilizers, the sum of inorganic $\mathrm{N}$ in the fertilizer is generally the best overall predictor of effects on yield, total $\mathrm{N}$ yield, and apparently bioavailable N (e.g., Svensson et al., 2004). Consequently, in this work, $\mathrm{N}_{\mathrm{EF}}$ (Eq. 1), net inorganic $\mathrm{N}$ equivalents (Eq. 2), and the apparent recovery fraction of $\mathrm{NH}_{4}-\mathrm{N}$ in applied effluent (Eq. 3) all refer to the ammonium $\mathrm{N}$ fraction of the effluent fertilizer, i.e., to an inorganic $\mathrm{N}$ equivalent.

$N_{E F}$. The amount of $\mathrm{NH}_{4}-\mathrm{N}$ available with the effluent within the $\mathrm{BG}$ system $\left(\mathrm{N}_{\mathrm{EF}}\right)$, assuming 1 ha of ley and 1 ha of red beets, was calculated as:

$$
\begin{aligned}
\mathrm{N}_{\mathrm{EF}}= & \left(\mathrm{N}_{\mathrm{H} \text {-ley }}+\mathrm{N}_{\mathrm{H} \text {-foliage }}\right) \\
& \times\left(\mathrm{NH}_{4} \mathrm{~N} \text { :Total } \mathrm{N}\right)
\end{aligned}
$$

where $\mathrm{N}_{\mathrm{H}-\text { ley }}$ is the amount of total $\mathrm{N}$ from harvested ley available for supply to the biodigestor. Data for the 2H-ley and $3 \mathrm{H}-\mathrm{ley}$ crop during the pre-crop year were used. Because biomass in harvested ley was measured on the flail forage harvester, no correction factor was used to obtain the harvestable fraction; $\mathrm{N}_{\mathrm{H} \text {-foliage }}$ is the amount of total $\mathrm{N}$ from harvested red beet foliage available for supply to the biodigestor in the BG system. The mean of red beet foliage data from Treatments VIII, IX, and X was used as an approximation for red beets grown with the amount of plant-available $\mathrm{N}$ present in a BG system. Red beet foliage was harvested by hand in the experiments. Therefore, for the amount of $\mathrm{N}$ in harvestable red beet foliage, a reduction factor of 0.66 was applied to compensate for the fact that only $\approx 66 \%$ can be harvested in practice by current machinery; $\mathrm{NH}_{4} \mathrm{~N}$ :total $\mathrm{N}$ is the ratio of $\mathrm{NH}_{4}-\mathrm{N}$ to total $\mathrm{N}$ in the effluent from biodigested plant material used in the experiment.

Net inorganic nitrogen equivalents. Net inorganic $\mathrm{N}$ equivalents refer to the amount of inorganic $\mathrm{N}$ from effluent plus inorganic $\mathrm{N}$ from pre-crops, the unit being kilograms (assuming 1 ha of red beets and 1 ha of ley in the crop sequence). Thus, the net inorganic $\mathrm{N}$ equivalents in crop Sequence $\mathrm{A}$ in the GrM system and Sequences B and $C$ within the BG system were calculated as:

$$
\begin{array}{r}
\text { Net inorganic } \mathrm{N} \text { equivalents }= \\
\mathrm{N}_{\mathrm{EF}}+\mathrm{N}_{\mathrm{R} \text {-ley }}+\mathrm{N}_{\mathrm{R} \text {-foliage }}
\end{array}
$$

where $\mathrm{N}_{\mathrm{EF}}$ is obtained from Eq. 1 and was thus 0 in the GrM system crop sequence; $\mathrm{N}_{\mathrm{R} \text {-ley }}$ was calculated from the amount of effluent $\mathrm{NH}_{4}-\mathrm{N}$ required for a red beet yield with barley as a pre-crop that corresponded to the marketable yield of red beets after ley. The equations for response curves presented in Figure 1 for red beets after barley (Treatments IV and VIII to XI) were used; $\mathrm{N}_{\mathrm{R} \text {-foliage }}$ was calculated on the basis of $\mathrm{N}$ and $\mathrm{C}$ in red beet foliage left in the field. The amount of mineralized $\mathrm{N}$ was calculated according to
Eq. 3 in Gunnarsson et al. (2008) on basis of the amounts of organic $\mathrm{C}$ and $\mathrm{N}$ in the plant material considered to remain in the soil after decomposition for this using the constant 0.26 for the humification coefficient (compare with Kolenbrander, 1974) and 10 for C/ $\mathrm{N}_{\text {org }}$ in humus. Finally, we assumed that $50 \%$ of the mineralized $\mathrm{N}$ corresponded to the first-year $\mathrm{N}$ fertilization effect, which is somewhat less than what can be estimated from sugar beet tops harvested in late October (Thomsen and Christensen, 1998). According to this, e.g., $20 \%$ of all $\mathrm{N}$ in the foliage in crop rotation A was considered $\mathrm{N}_{\mathrm{R} \text {-foliage }}$. This $\mathrm{N}$ effect of red beet foliage is at the higher end of what can be anticipated for the region and assumes forage handling that minimizes the risk of losses and drilling rye in early September as a subsequent crop (review by Lindén, 2008, used as the basis for fertilization recommendations by the Swedish Board of Agriculture). When $\mathrm{N}_{\mathrm{R} \text {-foliage }}$ was calculated for the BG systems, the mean of red beet foliage data from Treatments VIII, IX, and X was used (data from Table 3 after taking account of the fact that $66 \%$ of the foliage was removed for biogas production)

The barley pre-crop was used as a zero level for the fertilization effect related to precrop inorganic $\mathrm{N}$ equivalents and was therefore not included in the equation for net inorganic $\mathrm{N}$ equivalents. The net inorganic $\mathrm{N}$ equivalents were only calculated for the systems that were self-sufficient in N. Data from Treatment V (GrM-ley/Low N-t) were therefore not used, because that treatment represents an import-dependent system, thus with different system boundaries than the other treatments.

Recovery fraction of $\mathrm{NH}_{4}-\mathrm{N}$ in effluent applied to red beets. Apparent recovery fraction of ammonium $\mathrm{N}$ in effluent was calculated as:

$$
\begin{aligned}
& \mathrm{NH}_{4}-\mathrm{N} \text { recovery fraction }= \\
& \quad\left(\mathrm{BN}_{\mathrm{F}}+\mathrm{N}_{\min F}-\mathrm{BN}_{0}-\mathrm{N}_{\min 0}\right) / \mathrm{N}_{\mathrm{F}}
\end{aligned}
$$

where $\mathrm{BN}_{\mathrm{F}}$ is the amount of $\mathrm{N}$ taken up by the red beet crop, excluding fibrous roots, in the effluent-fertilized treatment in question; $\mathrm{BN}_{0}$ is the amount of $\mathrm{N}$ taken up by the red beet crop, excluding fibrous roots, in the treatment with the same pre-crop but without addition of effluent; $\mathrm{N}_{\min }$ is $\mathrm{N}_{\min }$ in the 0 - to $90-\mathrm{cm}$ layer at red beet harvest in the effluent-fertilized treatment in question.

$\mathrm{N}_{\min 0}=\mathrm{N}_{\min }$ in the 0 - to $90-\mathrm{cm}$ layer at red beet harvest in the treatment with the same pre-crop but without addition of effluent; $\mathrm{N}_{\mathrm{F}}$ is the amount of effluent $\mathrm{NH}_{4}-\mathrm{N}$ applied. 'Apparent' is used because part of the recovered $\mathrm{N}$ may be derived from organic $\mathrm{N}\left(\mathrm{N}_{\text {org }}\right)$ in the effluent that has been mineralized after supplied to the soil.

Residual nitrogen of ley. Residual N of ley is the increase of $\mathrm{N}$ in red beet plants and as $\mathrm{N}_{\min }(0$ to $60 \mathrm{~cm})$ in the year after ley compared with barley as the pre-crop and was calculated as: 
Marketable root yield, $\mathrm{Mg}$ ha

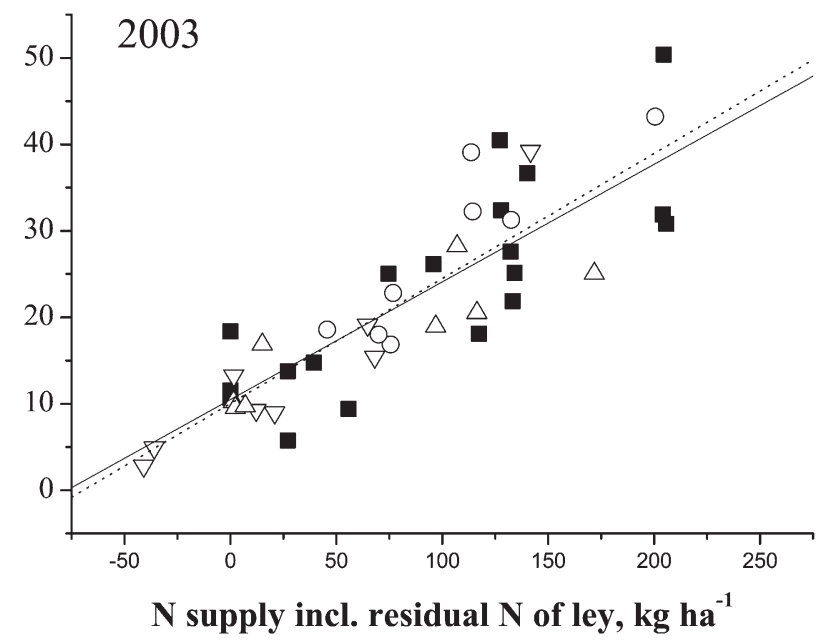

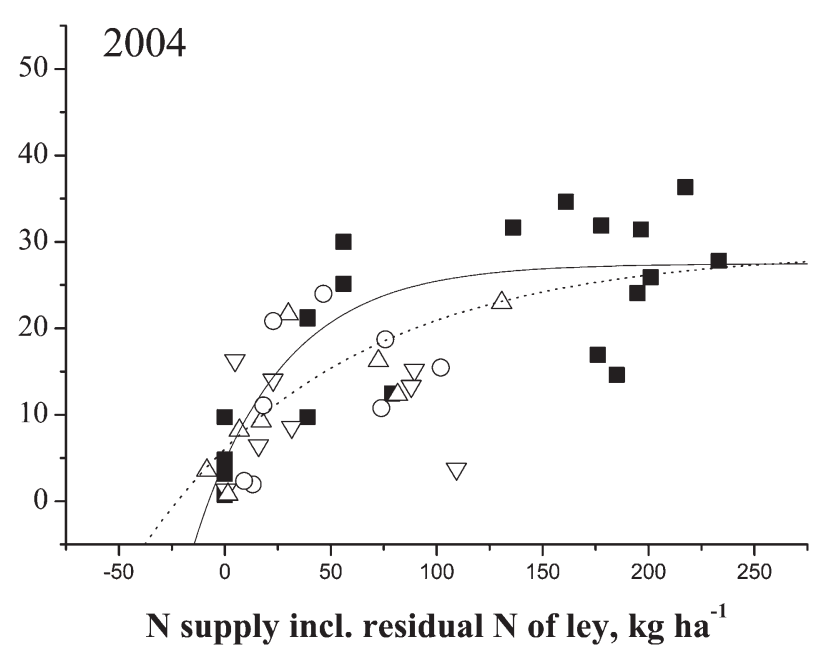

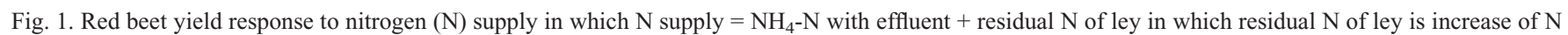
uptake in plants and $\mathrm{N}_{\min }$ at harvest in red beets after ley compared with in red beets after barley (see Eq. 4). Dotted lines: all data included; solid lines: only data from red beets after barley included in the analysis. $\mathrm{N}$ supply $=\mathrm{NH}_{4}-\mathrm{N}$ with effluent + residual $\mathrm{N}$ of ley in which residual $\mathrm{N}$ of ley is increase of $\mathrm{N}$ uptake in plants and $\mathrm{N}_{\min }$ at harvest in red beets after ley compared with in red beets after barley (see Eq. 4). Eqs. 2003 (linear response): barley pre-crops: $\mathrm{Y}=10.491$ $+0.136 \mathrm{X}\left(R^{2}\right.$ adj 0.66$)$; all pre-crops: $\mathrm{Y}=10.025+0.145\left(R^{2}\right.$ adj 0.74$)$. Eqs. 2004 (monomolecular response): barley pre-crops: $\mathrm{Y}=27.461\left\{1-\mathrm{e}^{-0.02426(\mathrm{X}+7.6)]}\right\}$ $\left(R^{2}\right.$ adj 0.60$)$; all pre-crops: $\mathrm{Y}=29.008\left\{1-\mathrm{e}^{[-0.01041(\mathrm{X}+22.5)]}\right\}\left(R_{\text {adj }}^{2} 0.50\right) . P$ values for regressions $<0.00001$.

Residual $\mathrm{N}$ of ley $=($ apparent soil $\mathrm{N}$ in

treatment with ley as pre-crop)

- (apparent soil $\mathrm{N}$ in treatment with

barley as pre-crop)

Apparent soil $\mathrm{N}$ included recovered $\mathrm{N}$ in total red beet plants, except fibrous roots, and $\mathrm{N}_{\text {min }} 0$ to 60. The way of calculating Apparent soil $\mathrm{N}$ is further described in Gunnarsson et al. (2008).

Sum of all nitrogen. The Sum of all $\mathrm{N}$ is the total amount of $\mathrm{N}$ in crop residues of ley and red beets plus harvested $\mathrm{N}\left(\mathrm{N}_{\mathrm{H}-\text { ley }}\right.$ and $\mathrm{N}_{\mathrm{H} \text {-foliage }}$ ) in the actual nutrient management system. For the harvested ley, the data on $\mathrm{N}$ in crop residues are based on the amounts left in October the pre-crop year. For green manure ley also, $\mathrm{N}$ cut and left on the ground in June and July in the pre-crop year is included. $\mathrm{N}$ in roots of ley is estimated as aboveground biomass $\mathrm{N}$ content $\times 0.33$ (compare with Hansson and Pettersson, 1989; Pettersson et al., 1986).

\section{Statistics}

Analysis of variance was performed on the data from the time of red beet harvesting, including $\mathrm{N}_{\text {min. }}$ (General Linear Model in Minitab 15; Minitab Inc.). Blocks and years were used as replicates. Analyses of $\mathrm{N}_{\min }$ and ratio $\mathrm{N}_{\text {min }}$ :root yield data were transformed to logarithmic scales to satisfy the assumptions in the model. All data were tested with Dunnett's two-sided test for differences to Treatment I (GrM/0 EF), because that treatment represented a control. Pairwise differences between the treatments were also evaluated with Tukey's test for least significant difference at the $P<0.05$ level. When the word "tendency" is used, it refers to results from a statistical analysis in which $0.05 \leq P<0.10$.

Data for $\mathrm{N}_{\mathrm{R}-\text { ley }}$, net inorganic $\mathrm{N}$ equivalents, and ratio for net inorganic $\mathrm{N}$ equivalents to the Sum of all N were statistically analyzed with a single-factorial model with all five combinations (GrM system, Sequence A; BG system, Sequence B or C and with two or three ley harvests) as treatments. In the single-factorial model, Dunnett's test was used for evaluating differences to the GrM system as the control. Dunnett's test was used when the $P$ value for treatments in the model was $<0.10$. Data for the BG systems were also statistically analyzed with a two-factorial model with harvests (two or three) and crop sequence ( $\mathrm{B}$ or $\mathrm{C}$ ) as factors. Because a difference in $\mathrm{N}_{\mathrm{R} \text {-ley, }}$, net inorganic $\mathrm{N}$ equivalents, and the ratio net inorganic $\mathrm{N}$ equivalents to Sum of all $\mathrm{N}$ between crop Sequences B and C was found in the two-factorial analysis $(P<$ $0.05,<0.10$, and $<0.05$, respectively), contrasts were made (Montgomery, 1997, p. 90 91) with crop Sequence B or C compared with the GrM system (Sequence A). Because the hypothesis was that the BG system would have lower $\mathrm{N}_{\mathrm{R} \text {-ley }}$ and higher net inorganic $\mathrm{N}$ equivalents and ratio net inorganic $\mathrm{N}$ equivalents to the Sum of all N, one-sided tests were used for the contrasts. In all other cases, twosided tests were used.

Unless otherwise stated, there was no significant interaction between treatments and years in the single-factorial analyses or between the factors in the two-factorial analyses.

Linear fits were made and analyzed statistically in Minitab 15 or Origin 8 (Origin$\mathrm{Lab}$ ), and for curvilinear fits, Origin 8 was used. For red beet yield versus N supply (Fig. 1), linear, linear plateau, monomolecular, and quadratic responses were tested. The equa- tions presented were the fits with the highest adjusted $R^{2}$. Linear plateau model was fitted to trial data as described by Uhte (1990). From the curve fit with $\mathrm{N}_{\text {min }}$ per unit marketable red beet versus root yield, the levels of the residuals was tested by analysis of variance for differences between ley pre-crops and barley.

\section{Results and Discussion}

Nitrogen to biodigestor and $\mathrm{NH}_{4}-\mathrm{N}$ in effluent $\left(N_{E F}\right)$. Mean total DM yield of harvested ley materiel in the two experimental periods was 6.1 and $9.0 \mathrm{Mg} \cdot \mathrm{ha}^{-1}$ in $2 \mathrm{H}$-ley and $3 \mathrm{H}-$ ley, respectively, containing 140 and $218 \mathrm{~kg} \mathrm{~N} /$ ha (Table 4; $\mathrm{N}_{\mathrm{H}-\mathrm{ley}}$ ). Harvestable red beet foliage contained $1.5 \mathrm{Mg} \mathrm{DM}$ and $34 \mathrm{~kg} \mathrm{~N} / \mathrm{ha}\left(\mathrm{N}_{\mathrm{H} \text {-foliage }}\right)$ with small differences between the years. Together, these gave a theoretical input to the biodigestor of 174 and $252 \mathrm{~kg} \mathrm{~N}$ from the BG system with $2 \mathrm{H}$ and $3 \mathrm{H}-\mathrm{ley}$, respectively, based on 1 ha of ley and 1 ha of red beets (= totally 2 ha). This $\mathrm{N}$ input to the biodigestor assumed that there were no $\mathrm{N}$ losses in the silage process, because the harvested ley material was stored as silage before digestion in the biodigestor. With an airtight silage seal, as used in this case, the $\mathrm{N}$ losses to the air should have been small or negligible, and silage effluent can be captured in the biodigestor.

According to the Bushwell equation (Bushwell and Mueller, 1952), a high degree of methane production from the carbon in a certain $\mathrm{N}$-containing organic material will give a higher ratio of mineralized $\mathrm{N}$ in the residues than if the methane production from the same material is low (Khanal, 2008, p. 38 ) although the relationship cannot be linear as a result of different $\mathrm{N}$ concentrations in 
different plant material fractions (Jensen et al., 2005). The $\mathrm{NH}_{4}-\mathrm{N}$ :total $\mathrm{N}$ ratio in our effluent in 2003 was 0.38 with methane production of $0.21 \mathrm{~m}^{3} \cdot \mathrm{kg}^{-1} \mathrm{VS}$. The relatively long fibers in ley biomass demand efficient stirring in large-scale biodigestors. In 2004, when the stirring equipment in the biodigestor was improved, the $\mathrm{NH}_{4}-\mathrm{N}$ :total $\mathrm{N}$ ratio increased to 0.46 and methane production to $0.25 \mathrm{~m}^{3} \cdot \mathrm{kg}^{-1} \mathrm{VS}$. In a further development of the biogas technique in 2005 to 2008 , the $\mathrm{NH}_{4}-\mathrm{N}$ :total $\mathrm{N}$ ratio in effluent from the same biodigestor became as high as 0.5 to 0.7 with a mean of 0.6 (results not shown). This suggests that the low $\mathrm{NH}_{4}-\mathrm{N}$ :total $\mathrm{N}$ ratio and methane production in 2003 was caused by insufficient stirring in our relatively large biodigestor. Ratios of 0.64 to 0.87 for $\mathrm{NH}_{4}$ $\mathrm{N}$ :total $\mathrm{N}$ in effluent from biodigested grassclover or lucerne have been reported from laboratory scale digestors ( 8 to $16 \mathrm{~L}$ ) (Nordberg et al., 2007; Zauner and Küntzel, 1986) and 0.57 for a biodigestor with 10 to $15 \mathrm{~m}^{3}$ active volume (Båth and Elfstrand, 2008).

Because the short-term $\mathrm{N}$ fertilization effect of $\mathrm{N}_{\text {org }}$ from residues of biodigested plant material is small or insignificant (Gunnarsson et al., 2010), the $\mathrm{NH}_{4}-\mathrm{N}$ :total $\mathrm{N}$ ratio is of great importance for the net inorganic $\mathrm{N}$ equivalents. With the actual $\mathrm{NH}_{4}-\mathrm{N}$ :total $\mathrm{N}$ ratio in the effluent from the biodigestor, the total amount of $\mathrm{NH}_{4}-\mathrm{N}$ that could be used as effluent fertilizer was $73 \mathrm{~kg}$ (digested from 1 ha of ley and 1 ha of red beet foliage) for the BG system type with $2 \mathrm{H}$-ley and $106 \mathrm{~kg}$ with $3 \mathrm{H}-$ ley as a 2 -year mean. However, because the low $\mathrm{NH}_{4}-\mathrm{N}$ :total $\mathrm{N}$ ratio in 2003 caused by insufficient stirring, we performed the calculations for $\mathrm{N}_{\mathrm{EF}}$ using the ratio 0.46 for $\mathrm{NH}_{4}-\mathrm{N}$ :total $\mathrm{N}$ for both years. The 2-year means became then 80 and $116 \mathrm{~kg} \mathrm{NH}_{4}-\mathrm{N}$, respectively.

Nitrogen supply effects on yield of and nitrogen uptake by red beets. Red beets not fertilized with effluent in Treatments II to IV yielded $\approx 10 \mathrm{Mg}$ marketable roots per ha, but after GrM-ley (Treatment I), the yield was 17 $\mathrm{Mg} \cdot \mathrm{ha}^{-1}$ (Table 3; not significantly different). For a yield of $25 \mathrm{Mg} \cdot \mathrm{ha}^{-1}$, an $\mathrm{N}$ supply of $\approx 100 \mathrm{~kg} \mathrm{NH}$-N/ha was needed and, as an average for the two experimental periods, a yield of $33 \mathrm{Mg} \cdot \mathrm{ha}^{-1}$ was achieved at $200 \mathrm{~kg}$ $\mathrm{NH}_{4}-\mathrm{N} /$ ha. The 2-year mean yield increase/ $\mathrm{kg} \mathrm{N}$ supplied with application of $100 \mathrm{~kg} \mathrm{~N} /$ ha and $200 \mathrm{~kg} \mathrm{~N} / \mathrm{ha}$ was 143 and $119 \mathrm{~kg}$ marketable red beets/ha, respectively (all precrops included, monomolecular model, $R^{2}$ adj $=$ $0.59, \mathrm{n}=88$ ). In general, the ranking between treatments on the basis of root yield followed the size of $\mathrm{N}$ supply. However, root and foliage biomass and $\mathrm{N}$ content of red beets in Treatment VII (3H-ley/Low N-t) were lower than expected from $\mathrm{N}$ supply.

The marketable root yield $\left(24 \mathrm{Mg} \cdot \mathrm{ha}^{-1}\right)$ in Treatment $\mathrm{V}$ with GrM-ley and added effluent (low N-t) was at the same level or somewhat higher than normal for organic red beet production in the region during these years. Yield levels and responses for $\mathrm{N}$ were both at the levels reported in previous studies on red beets and $\mathrm{N}$ fertilization with mineral $\mathrm{N}$. 
Table 4. Mean of two experimental periods for nitrogen $(\mathrm{N})\left(\mathrm{kg} \cdot \mathrm{ha}^{-1}\right)$ from grass-clover ley and red beet foliage in the crop sequences representing systems with and without biogas production. ${ }^{\mathrm{z}}$

$\mathrm{N}$ in ley and red beet foliage $\left(\mathrm{kg} \cdot \mathrm{ha}^{-1}\right)$

\begin{tabular}{|c|c|c|c|c|c|c|}
\hline \multirow{3}{*}{$\begin{array}{l}\text { Nutrient } \\
\text { management } \\
\text { system }^{\mathrm{y}}\end{array}$} & \multicolumn{3}{|c|}{ Total $\mathrm{N}$ in crop residues } & \multirow{2}{*}{\multicolumn{2}{|c|}{ Total $\mathrm{N}$ in effluent }} & \multirow{3}{*}{$\frac{\text { Sum of all N }}{\sum}$} \\
\hline & \multirow{2}{*}{$\begin{array}{c}\text { Ley, } \\
\text { aboveground }\end{array}$} & \multirow{2}{*}{$\begin{array}{c}\text { Roots } \\
\left(\text { estimated }^{\mathrm{x}}\right)\end{array}$} & \multirow{2}{*}{$\begin{array}{l}\text { Red beet } \\
\text { foliage }\end{array}$} & & & \\
\hline & & & & $\mathrm{N}_{\mathrm{H}-\mathrm{ley}}$ & $\mathrm{N}_{\mathrm{H} \text {-foliage }}$ & \\
\hline GrM system & 282 & 94 & 46 & 0 & 0 & 422 \\
\hline BG system, 2H-ley & 70 & 79 & 17 & 140 & 34 & 340 \\
\hline BG system, 3H-ley & 13 & 87 & 17 & 218 & 34 & 369 \\
\hline SEM $^{\mathrm{w}}$ & 7 & 6 & 2 & 2 & 3 & 22 \\
\hline
\end{tabular}

${ }^{2}$ Data for total $\mathrm{N}$ in ley crop residues refer to $\mathrm{N}$ in crop residues left in October in the pre-crop year and for the green manure ley (GrM-ley) also including $\mathrm{N}$ that was cut and left on the ground in June and July (presented previously in Gunnarsson et al., 2008). Data for total $\mathrm{N}$ in effluent refer to amount of total $\mathrm{N}$ available for supply to the biodigestor, assuming no $\mathrm{N}$ losses, in which the index ${ }_{\mathrm{H}}$ in $\mathrm{N}_{\mathrm{H} \text {-ley }}$ and $\mathrm{N}_{\mathrm{H} \text {-foliage }}$ stands for harvested as the columns show the amount of $\mathrm{N}$ in the harvested part of ley biomass and beet foliage in the BG nutrient management systems.

${ }^{\mathrm{y}} \mathrm{GrM}$ system $=$ green manure system; $\mathrm{BG}$ system $=$ biogas system; $2 \mathrm{H}$-ley and $3 \mathrm{H}$-ley $=$ ley for biogas production harvested two or three times.

${ }^{\mathrm{x}} \mathrm{N}$ aboveground at harvest or cutting times in June, July, and October $\times 0.33$ (compare with Hansson and Pettersson, 1987).

${ }^{\mathrm{w}} \mathrm{SEM}=$ standard error of mean.

However, local conditions always determine the response to applied $\mathrm{N}$ fertilizer. Takácsné Hájos et al. (1997) in Hungary reported optimum $\mathrm{N}$ fertilization to irrigated red beets as low as $70 \mathrm{~kg} \mathrm{~N} / \mathrm{ha}$ with a yield of $27 \mathrm{Mg} \cdot \mathrm{ha}^{-1}$ and with a mean increase of $43 \mathrm{~kg}$ of marketable roots per $\mathrm{kg}$ added $\mathrm{N}$ at that fertilization level. Greenwood et al. (1980) in the United Kingdom reported a higher response for $\mathrm{N}$ to red beets with an optimum of $245 \mathrm{~kg} \mathrm{~N} / \mathrm{ha}$ at a yield of $62 \mathrm{Mg} \cdot \mathrm{ha}^{-1}$ and a mean increase of $133 \mathrm{~kg}$ of marketable roots per $\mathrm{kg}$ added $\mathrm{N}$ at the level of $245 \mathrm{~kg} \cdot \mathrm{ha}^{-1}$. Differences in response between the years in the present investigation can mainly be understood by later planting date in 2003, a larger amount of $\mathrm{N}_{\text {min }}$ at planting (48 kg N/ha in 2003 and 31 $\mathrm{kg} \mathrm{N} / \mathrm{ha}$ in 2004 with barley pre-crop, data not shown), higher level of soil $\mathrm{N}$ mineralization after planting in 2004 in the middle of June when the most intensive growth period started in both years, the apparent available $\mathrm{N}$ $\left[\mathrm{N}_{\min (0-60 \mathrm{~cm})}+\mathrm{N}\right.$ in plant] was $78 \mathrm{~kg}$ in 2003 and $91 \mathrm{~kg} \mathrm{~N} / \mathrm{ha}$ in 2004, in the unfertilized treatment with barley as pre-crop, data not shown \}, and low potential yield in 2004 resulting from rainy weather in July and August.

The ratio of marketable yield ( $\varnothing 30$ to $75 \mathrm{~mm}$ ) to total yield showed a monomolecular relationship to total root yield with $R^{2}$ adj of 0.76 and an asymptote at $93 \%$ marketable yield at the highest yield levels (data not shown). In most plots with a yield level above $20 \mathrm{Mg} \cdot \mathrm{ha}^{-1}, 90 \%$ of the yield was in the marketable fraction. Marketable red beet yield increased linearly with increasing $\mathrm{N}$ supply in 2003 and gave a monomolecular response in 2004 (Fig. 1). Because $\mathrm{N}$ in the red beet plants with spring barley as a pre-crop, and corresponding $\mathrm{N}_{\min }$ at harvest, was used as a zero level when calculating the residual $\mathrm{N}$ effect of ley (Eq. 4), N supply corresponded to $\mathrm{NH}_{4}-\mathrm{N}$ supply with effluent where the precrop was barley. With the figures 80 and 116 $\mathrm{kg} \cdot \mathrm{ha}^{-1}$ of $\mathrm{N}$ from $\mathrm{N}_{\mathrm{EF}}$ (as estimated previously to be available from $2 \mathrm{H}$-ley and $3 \mathrm{H}$ ley crop sequences, respectively) entered in the yield response equations for red beets after barley (Fig. 1), the mean yield, for both years, of marketable red beets after spring barley was calculated to be $22.8 \mathrm{Mg} \cdot \mathrm{ha}^{-1}$ for a $\mathrm{BG}$ system with crop rotation $\mathrm{C}$ (harvested ley - spring barley - red beets) and $2 \mathrm{H}$-ley and $26.2 \mathrm{Mg} \cdot \mathrm{ha}^{-1}$ with $3 \mathrm{H}$-ley. This corresponds to a yield increase of $33 \%$ and $53 \%$, respectively, compared with the 17.1 ton red beets per ha in the control Treatment I (GrM/ 0 EF; Table 3), i.e., compared with GrM preceding red beets as in crop rotation A. Yield increase was $29 \%$ and $44 \%$, respectively, if dry weight in the total root yield was taken into account instead of marketable fresh weight yield. When total DM production inclusive of foliage was considered, the advantage for $\mathrm{BG}$ systems with $2 \mathrm{H}-$ and $3 \mathrm{H}-$ ley was only $15 \%$ and $28 \%$ as beets after GrM-ley gave a larger portion of biomass in foliage than the effluent fertilized beets after barley. Other field studies with a cropping system approach report positive yield effects (10\% yield increase; Stinner et al., 2008) or non-significant yield influences (Båth and Elfstrand, 2008; Ross et al., 1989) in systems using effluent from biodigested plant material as fertilizers to non-leguminous crops. The differences may be the result of experimental sites with different preconditions for $\mathrm{N}$ losses from green manure resulting from leaching or denitrification, different application strategies, or different levels of net mineralization of $\mathrm{N}$ in native soil organic matter. Growth-limiting factors other than $\mathrm{N}$ may also explain the absence of a yield increase, like in two of the cited references. Moreover, differences in ammonia losses after application of the effluents resulting from spreading technique could affect $\mathrm{N}$ use efficiency (Möller and Stinner, 2009).

Quality effects. Treatments X and XI (barley/3 N-t and barley/4 N-t) resulted in higher $\mathrm{NO}_{3}{ }^{-}$concentrations in red beets than in the other treatments where this was measured (Table 3 ). There was a significant linear increase in $\mathrm{NO}_{3}{ }^{-}$in red beets $\left(\mathrm{Y}, \mathrm{mg} \mathrm{NO}_{3}{ }^{-} / \mathrm{kg}\right.$ ) with increasing $\mathrm{N}$ supply ( $\mathrm{kg} \mathrm{N} / \mathrm{ha}$ ) with the equation $\mathrm{Y}=66+2.5 \times \mathrm{N}$ supply $(P<0.001$; $\left.R^{2}=0.31\right)$. Applying this equation to $\mathrm{N}_{\mathrm{EF}}$ on a BG system with $3 \mathrm{H}-\mathrm{ley}$ and crop Sequence $\mathrm{C}$ (red beets after barley, effluent based on 1 ha $3 \mathrm{H}-$ ley and 1 ha beet foliage for each hectare of red beets) and assuming that all the effluent is supplied to the red beets gives a beet $\mathrm{NO}_{3}$ concentration less than $400 \mathrm{mg} \cdot \mathrm{kg}^{-1}$.

Red beet is a vegetable with among the highest nitrate concentrations. Contents above $2500 \mathrm{mg} \mathrm{NO}_{3}{ }^{-} / \mathrm{kg}$ are common and maximum levels in commercial red beets range from 3000 to $4500 \mathrm{mg} \mathrm{NO}_{3}{ }^{-} / \mathrm{kg}$ in countries with limits for red beets (Santamaria, 2006). In our experiments, the levels were higher in 2003 than in 2004 and the highest concentration was $1070 \mathrm{mg} \cdot \mathrm{kg}^{-1}$, which was found in 2004 in Treatment X. Thus, the beet nitrate contents in the current experiments were low compared with normally accepted values for food to adults. Although recent reports show that the blood pressure-lowering effect of red beet juice can be explained by a high $\mathrm{NO}_{3}{ }^{-}$content (Webb et al., 2008), experts generally agree that high levels of nitrate in vegetables should be avoided (Santamaria, 2006). However, our results indicate that with the moderate $\mathrm{N}$ supply expected on organic farms that are $\mathrm{N}$ self-sufficient, the beet $\mathrm{NO}_{3}{ }^{-}$levels should not constitute a health problem.

The beet DW:fresh weight (FW) ratio was between 0.15 and 0.17 with a significant negative correlation with increasing cumulative supply of residual $\mathrm{N}$ from ley pre-crops plus total $\mathrm{NH}_{4}-\mathrm{N}$ added with effluent (data not shown). However, $R_{\text {adj }}^{2}$ was only 0.21 . No treatment differed significantly from the control treatment as regarding the DW:FW ratio.

Nitrogen fertilization effect of residues of red beet foliage and ley left in the field $\left(N_{R \text {-foliage }}\right.$ and $\left.N_{R \text {-ley }}\right)$. As a 2-year mean, $\mathrm{N}_{\mathrm{R}-\text { ley }}$ increased in the order $3 \mathrm{H}-\mathrm{ley}<2 \mathrm{H}$-ley $<$ GrM-ley (Table 5), which was expected according to the apparent net mineralization presented by Gunnarsson et al. (2008). The $\mathrm{N}_{\mathrm{R} \text {-ley }}$ was smaller in crop Sequence B than in C. (To interpret this, we remind of that the concept $\mathrm{N}_{\mathrm{R} \text {-ley }}$ and the concept residual $\mathrm{N}$ of ley used in this article are not equivalent; see section "Materials and Methods.") In crop Sequence B, $\mathrm{N}_{\mathrm{R} \text {-ley }}$ was even negative as compared with the $\mathrm{N}$ conditions with spring barley as a pre-crop, constituting the zero value of $\mathrm{N}_{\mathrm{R}-\mathrm{ley}}$. For example, in 2004, in Treatments VII (3H-ley pre-crop) and IX (barley pre-crop), the same target values were used: $75 \mathrm{~kg} \mathrm{~N} / \mathrm{ha}$ before planting, $170 \mathrm{~kg} \mathrm{~N} /$ ha in June, and $80 \mathrm{~kg} \mathrm{~N} / \mathrm{ha}$ in July. The amount of $\mathrm{NH}_{4}-\mathrm{N}$ supplied with effluent was $92 \mathrm{~kg} \cdot \mathrm{ha}^{-1}$ in Treatment VII and $106 \mathrm{~kg} \cdot \mathrm{ha}^{-1}$ in Treatment IX. Still the root yield in Treatment VII was only $11.6 \mathrm{t} \cdot \mathrm{ha}^{-1}$, but in Treatment IX, it was $25.9 \mathrm{t} \cdot \mathrm{ha}^{-1}$. To continue with that example, the yield in Treatment VII corresponded to an N supply of $15 \mathrm{~kg} \mathrm{~N} / \mathrm{ha}$ using the equation in Figure 1 for 2004 with barley as the pre-crop. However, because the actual supply was $92 \mathrm{~kg} \mathrm{NH}_{4}-\mathrm{N}$, the $\mathrm{N}_{\mathrm{R} \text {-ley }}$ in this case becomes $-77 \mathrm{~kg} \mathrm{NH}-\mathrm{N}$ (i.e., 15 minus 92). This indicates that fertilizing the red beet crop with biogas effluent up to a certain $\mathrm{N}$ target value, with harvested ley as a pre-crop, is less efficient than using the 
Table 5. Nitrogen $(\mathrm{N})$ fertilization effect of ley residues left in the field $\left(\mathrm{N}_{\mathrm{R}-\mathrm{ley}}\right)$, net inorganic $\mathrm{N}$ equivalents as influenced by all crops in each crop sequence, and $\mathrm{N}$ use efficiency (expressed as the ratio for net inorganic $\mathrm{N}$ equivalents relative to the Sum of all N) derived from grass-clover ley and red beet foliage (see Table 4) in the nutrient management systems with and without biogas production. ${ }^{\mathrm{z}}$

\begin{tabular}{|c|c|c|c|c|c|}
\hline $\begin{array}{l}\text { Nutrient } \\
\text { management } \\
\text { system }\end{array}$ & $\begin{array}{c}\text { Ley } \\
\text { harvests }\end{array}$ & Crop sequence & $\begin{array}{c}\mathrm{N}_{\text {R-ley }} \\
\left(\mathrm{kg} \cdot \mathrm{ha}^{-1}\right)\end{array}$ & $\begin{array}{l}\text { Net inorganic } \\
\mathrm{N} \text { equivalents }\end{array}$ & $\begin{array}{l}\text { Ratio of net } \\
\text { inorganic N } \\
\text { equivalents } t \\
\text { Sum of all }\end{array}$ \\
\hline \multicolumn{6}{|c|}{ Analysis with one factorial model } \\
\hline GrM (control) & - & A (Ley, red beets, winter rye) & 64 & 73 & 0.19 \\
\hline $\mathrm{BG}$ & 2 & B (Ley, red beets, winter rye) & -2 & 89 & 0.26 \\
\hline BG & 3 & B (Ley, red beets, winter rye) & $-52 * * *$ & 58 & 0.16 \\
\hline BG & 2 & C (Ley, barley, red beets) & 22 & 99 & 0.29 \\
\hline BG & 3 & C (Ley, barley, red beets) & 27 & $158 \mathrm{t}$ & $0.43 \mathrm{t}$ \\
\hline \multicolumn{6}{|c|}{ Analyses for contrasts to GrM (control), one-sided test ${ }^{\mathrm{x}}$} \\
\hline BG & Mean & B (Ley, red beets, winter rye) & $-27 *$ & 74 & 0.21 \\
\hline BG & Mean & C (Ley, barley, red beets) & $24 * * *$ & $129 *$ & $0.36^{*}$ \\
\hline \multicolumn{3}{|c|}{ Analysis, two factorial model, $P$} & $P$ & & \\
\hline \multicolumn{3}{|c|}{ Harvests in biogas ley: 2 or 3} & 0.27 & 0.62 & 0.78 \\
\hline \multicolumn{3}{|c|}{ Crop rotation in biogas systems: $\mathrm{B}$ or $\mathrm{C}$} & $<0.05$ & $<0.10$ & $<0.05$ \\
\hline
\end{tabular}

${ }^{\mathrm{z} T h e}$ zero value for $\mathrm{N}_{\mathrm{R} \text {-ley }}$ refers to the conditions with spring barley as pre-crop. Means for both experimental periods. GrM = green manure system; $\mathrm{BG}=$ biogas system. The net inorganic $\mathrm{N}$ equivalents are expressed in kilograms from 1 ha red beets and 1 ha of ley. Asterisks show significant differences to the control according to Dunnett's two-sided test in a one-factorial model or, for mean of the ley harvest regimes, according to contrasts to the control: $* P<0.05 ; * * * P<0.001 . t=$ tendency: $P<0.1$.

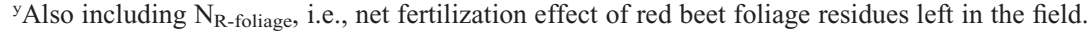

${ }^{\mathrm{x}}$ One-sided test in accordance with the hypotheses.

effluent on red beets after barley. This could only be explained to a very limited extent by starting on a higher level of the response curve when adding effluent to red beets after ley than after barley. The main factor causing low $\mathrm{N}_{\mathrm{R} \text {-ley }}$ in the $\mathrm{BG}$ system with crop Sequence $\mathrm{B}$ in general and within the $\mathrm{BG}$ system with $3 \mathrm{H}-\mathrm{ley}$ and crop Sequence B in particular was the low yield response to effluent supply to red beets after harvested ley (Treatments VI and VII in Table 3 and $\mathrm{N}_{\mathrm{R} \text {-ley }}$ rotation $\mathrm{B}$ in Table 5). Factors other than $\mathrm{N}$ may have limited the growth of red beets after harvested ley. Large amounts of nutrients are removed with the harvested ley and the relatively low levels of effluent in the harvested ley treatments may not have compensated fully for harvested nutrients. Hence, nutrients other than $\mathrm{N}$ may have been limiting, both as regarding $\mathrm{N}$ mineralization (compare with Campino, 1982) and red beet growth. Crop residues from Trifolium spp., other plants, and organic waste can have conducive effects on the root pathogens Pythium spp. and Rhizoctonia solani, both of which harm red beet plants in early stages (Bonanomi et al., 2007). To our knowledge, biogas effluent has not been studied in this regard.

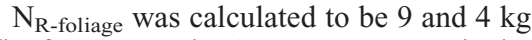
N/ha for GrM and BG systems, respectively, with small differences between the two trials (data not shown). The differences between the GrM and BG systems were statistically significant. In absolute values, however, those differences were much smaller than the differences in $\mathrm{N}_{\mathrm{R} \text {-ley }}$ (Table 5).

Net inorganic nitrogen equivalents. In the $\mathrm{BG}$ system with crop sequence $\mathrm{C}(2 \mathrm{H}$ or $3 \mathrm{H}-$ ley - barley - red beets), Net inorganic $\mathrm{N}$ equivalents were on average $56 \mathrm{~kg}$ higher than in the GrM crop sequence A (green manure ley - red beets - winter rye), whereas the BG system with crop sequence B $(2 \mathrm{H}$ or $3 \mathrm{H}$-ley - red beets - winter rye) did not differ from the GrM crop sequence (Table $5)$. The amount of net inorganic $\mathrm{N}$ equivalents did not differ significantly between the $\mathrm{BG}$ system with $2 \mathrm{H}-\mathrm{ley}$ and that with $3 \mathrm{H}-\mathrm{ley}$ (Table 5).

In crop Sequence A (green manure ley - red beets - winter rye), the red beets were supplied with $\mathrm{N}$ as a result of the residual effect of the green manure ley, the effect depending on the synchrony between the rate of $\mathrm{N}$ mineralization and $\mathrm{N}$ uptake by the beets. Because beet foliage was left in the field, its mineralized $\mathrm{N}$ may have been exposed to $\mathrm{N}$ losses by volatilization and leaching during the fall and winter, although the rye crop was assumed to be established as soon as possible after beet harvest to favor $\mathrm{N}$ uptake during fall and to reduce losses.

In crop Sequence B $(2 \mathrm{H}$ or $3 \mathrm{H}-\mathrm{ley}-$ red beets - winter rye), the $\mathrm{N}$ supply to red beets was affected negatively by the number of harvests of the ley and the resulting smaller amounts of crop residues in $3 \mathrm{H}-$ ley than in $2 \mathrm{H}$ ley, but it was also affected positively by the corresponding increased amount of effluent $\mathrm{N}$ from the biodigestor. Because red beet foliage was harvested here, less foliage was left on the ground than in Sequence A. This must have reduced the risk of leaching, but the $\mathrm{N}$ supply to rye was somewhat lower than in Sequence A.

In crop rotation $\mathrm{C}(2 \mathrm{H}$ or $3 \mathrm{H}$ - ley - barley red beets), only the barley was likely to be affected by the residual effect of ley. The second-year effect of a 1-year ley is small (Granstedt and L-Baeckström, 2000). Therefore, we did not calculate with a second-year effect of ley in any of the crop sequences. The beets were supplied with $\mathrm{N}$ from effluent. In Sequence C, the beet foliage was harvested, thus causing less $\mathrm{N}$ losses than in Sequence A (compare with Thomsen and Christensen, 1998).
In general, $\mathrm{N}_{\mathrm{R} \text {-foliage }}$ had little effect on the differences in net inorganic $\mathrm{N}$ equivalents between the crop sequences. Foliage $\mathrm{N}$ yield was moderate, in general 40 to $50 \mathrm{~kg} \cdot \mathrm{ha}^{-1}$ (Table 3 ) and although the beet crop was assumed to be followed by winter rye, the residual effect of non-harvested beet foliage should generally have been small (compare with review by Lindén, 2008).

The amount of net inorganic $\mathrm{N}$ equivalents in the 2 years differed clearly, although there were no interactions between treatments and years. The BG system was more advantageous compared with the GrM system in 2003-2004 than it was in 2002-2003 (data not shown). In 2002-2003, the net inorganic $\mathrm{N}$ equivalents in the BG system with rotation $\mathrm{C}$ were $146 \mathrm{~kg}$, compared with $116 \mathrm{~kg}$ in the GrM crop with sequence (A), whereas the corresponding net inorganic $\mathrm{N}$ equivalents in 2003-2004 were 110 and $30 \mathrm{~kg}$, respectively. The main reasons for the greater advantage of the BG systems in 2003-2004 than in 2002-2003 were: 1) lower $\mathrm{N}$ yield of harvested ley in 2002 than in 2003; and 2) greater $\mathrm{N}_{\mathrm{R} \text {-ley }}$ of GrM-ley in the first experimental period compared with $\mathrm{N}_{\mathrm{R} \text {-ley }}$ of harvested ley. This may be the result of greater $\mathrm{N}$ leaching in 2004 than in 2003 probably causing more leaching of mineralized $\mathrm{N}$ from GrM-ley than from the other pre-crops. In an adjacent comparable field with lysimeters, the accumulated runoff for July, Aug., and Sept. 2004 was $55 \mathrm{~mm}$ in 2003 and $220 \mathrm{~mm}$ in 2004 , and $\mathrm{N}$ leaching during these months amounted to 1 and $13 \mathrm{~kg}$ of $\mathrm{N} / \mathrm{ha}$ for 2003 and 2004, respectively (G. Torstensson, personal communication).

For growers familiar with animal manure, the concept of the net inorganic $\mathrm{N}$ equivalents should give understandable information about the summarized differences in $\mathrm{N}$ supply to crops between the BG and GrM crop sequences. However, if transferring the expression net inorganic $\mathrm{N}$ equivalents used in this work to fertilizer value of commercial inorganic $\mathrm{N}$ fertilizers, e.g., $\mathrm{NH}_{4} \mathrm{NO}_{3}$, account must be taken of the greater $\mathrm{NH}_{3}$ emissions from the effluent, among other things. Because effluent was incorporated into the soil within $1 \mathrm{~h}$ of spreading in the present experiment, such losses would not have been large. Account should also be taken of possible mineralization of $\mathrm{N}_{\text {org }}$ in the effluent. With a mineralization rate corresponding to $12 \%$ of $\mathrm{N}_{\text {org }}$ in a 6-month period (compare with Gunnarsson et al., 2010), the net contribution of such mineralized $\mathrm{N}_{\text {org }}$ would be of the same magnitude as the $\mathrm{NH}_{3}$ losses (compare with Sommer and Hutchings, 2001).

Our results refer to a sandy soil and a maritime, humid climate. A soil with higher clay content may give other results. The relation between GrM-ley and harvested ley may differ concerning production of biomass and $\mathrm{N}$ (probably an advantage for the BG system). Nitrogen leaching caused by GrMley may be lower with increasing clay content and less precipitation (an advantage for the GrM system). Denitrification may be higher in clayey soils (an advantage for the BG system). The net effect is difficult to forecast. 
Ratio of net inorganic nitrogen equivalents to Sum of all $N$ in ley and red beet foliage (nitrogen use efficiency). The ratio of net inorganic $\mathrm{N}$ equivalents to the Sum of all $\mathrm{N}$ in ley and red beet foliage was higher for the BG system with crop Sequence C than for the GrM system (Table 5). This indicates a better $\mathrm{N}$ use efficiency in the BG system. However, for the BG system with crop Sequence B, the ratio did not differ significantly from the GrM system.

Recovery fraction of $\mathrm{NH}_{4}-\mathrm{N}$ in effluent applied to red beets. The overall mean for the $\mathrm{NH}_{4}-\mathrm{N}$ recovery fraction (Eq. 3) was 0.73 with no statistically significant differences between treatments or years (results not shown). Gunnarsson et al. (2010) reported that $175 \mathrm{~d}$ after application of a similar effluent used as fertilizer to ryegrass in a pot experiment, the total $\mathrm{N}$ recovery (in plant, roots, and as unused $\mathrm{N}_{\min }$ ) corresponded to $100 \%$ of the $\mathrm{NH}_{4}-\mathrm{N}$ plus $12 \%$ of $\mathrm{N}_{\text {org }}$ added with the effluent. The lower $\mathrm{N}$ recovery during cultivation of red beets in the present field study may be explained by a shorter growing period and a different crop and also by the effects of field conditions such as more pronounced ammonia volatilization and $\mathrm{N}$ leaching and by the fact that fibrous roots were not included when calculating $\mathrm{N}$ recovery. Denitrification was probably a less plausible reason, because a sandy soil does not offer a beneficial environment for denitrification (Włodarczyk et al., 2004). In a "healthy" biogas process, the VFA concentration in the effluent is relatively low, usually in the range corresponding to 0.05 to $0.25 \mathrm{~g}$ acetic acid/L (Sawyer et al., 2003, cited by Khanal, 2008, p. 58). VFA and lactate may cause $\mathrm{N}$ immobilization when fertilizing with farm manure that has not been processed in a biodigestor or with biogas effluent that, as a result of an "unhealthy" anaerobic pro- cess, has high levels of VFA (Kirchmann and Lundvall, 1993). In our experiment, immobilization should not have been severe as the concentrations of VFA and lactate were low. We applied some of the effluent in the growing season of the red beet crop and although soil tillage was performed within $1 \mathrm{~h}$ of effluent application, there may have been some ammonia losses.

Effects of $N_{\text {min }}$ after red beet harvest. The amounts of $\mathrm{N}_{\min }$ remaining unused at red beet harvest in the $0-$ to $90-\mathrm{cm}$ soil layer were largest in treatment $\mathrm{V}(\mathrm{GrM} / \mathrm{Low} \mathrm{N}-\mathrm{t})$ and smallest in treatment IV (Barley/0 EF; Fig. 2). All treatments with spring barley as a precrop and Treatment III with $3 \mathrm{H}$-ley as a precrop and $0 \mathrm{EF}$ had less $\mathrm{N}_{\min }$ than the control (red beets after GrM-ley/0 EF). The ranking between treatments was similar when only $\mathrm{N}_{\min }$ in the 0 - to 60 -cm layer was considered. There was no statistically significant correlation between $\mathrm{N}_{\min }$ within 0 to $90 \mathrm{~cm}$ and the total $\mathrm{N}$ supply, i.e., supply with effluent and residual $\mathrm{N}$ from ley.

Red beet has been classified as a deeprooted crop (Christiansen et al., 2006). However, in our experimental soil, with its low clay and $\mathrm{C}$ content in the subsoil, the roots cannot be expected to have reached the $60-$ to $90-\mathrm{cm}$ soil layer (review by Heinonen, 1985, p. 51) and obviously could not use $\mathrm{N}_{\text {min }}$ that moved down to that layer, especially in 2004 (Fig. 2).

Significantly more unused $\mathrm{N}_{\text {min }}$ per unit marketable roots was found in the control treatment (I; GrM-Ley/0 EF) than in Treatments IX to XI with a barley pre-crop and the largest effluent supply (Table 3 ). The amount of $\mathrm{N}_{\text {min }}$ per unit marketable red beet showed an exponentially declining response to yield $\left(R_{\text {adj }}^{2}=0.95\right)$. However, the model residuals were positive in treatments with ley as a precrop and negative in treatments with barley as a pre-crop $(P<0.01$, all observations included; $P<0.1$, only effluent-fertilized treatments included). The larger residuals with leys as a pre-crop indicate that the synchrony of $\mathrm{N}$ release from ley residues with $\mathrm{N}$ uptake by red beets was not optimal throughout the growing season.

The smaller amounts of unused $\mathrm{N}_{\text {min }}$ in the effluent-fertilized treatments with red beets after barley than with red beets in the control treatment (I) indicate that risk for leaching is lower in a BG system with crop Sequence $\mathrm{C}$ than in a GrM system with crop Sequence A. Furthermore, leaching of $\mathrm{N}$ in the treatment with GrM-ley as well as with $2 \mathrm{H}-$ ley may have been larger than with $3 \mathrm{H}$ ley during the winter before the red beets, although the leys were incorporated with a disc harrow and ploughed late in spring. The risk of leaching after barley after harvested ley in crop Sequence C must also be taken into account for a full judgment of crop Sequence C compared with A. However, this may be avoided by an undersown catch crop in barley, as used in our experiment in the pre-crop year. Harvesting the cereal straw in BG systems for use in the biodigestor may increase the risk of leaching in the first years, as a result of less $\mathrm{N}$ immobilization, but only to a small extent (Myrbeck et al., 2006). However, the long-term effects of harvesting the straw would lead to somewhat lesser $\mathrm{N}_{\text {min }}$ during fall and winter, indicating decreased amounts of mineralizable organic $\mathrm{N}$ in the soil compared with continuous incorporation of straw according to a 12-year study by Myrbeck et al. (2006). Moreover, applications of effluent may cause a minor increase in $\mathrm{N}_{\min }$ in the fall after harvest as a result of a continued mineralization of $\mathrm{N}_{\text {org }}$ in the effluent after harvest of red beets (compare with Gunnarsson et al., 2010). Thus, an awareness

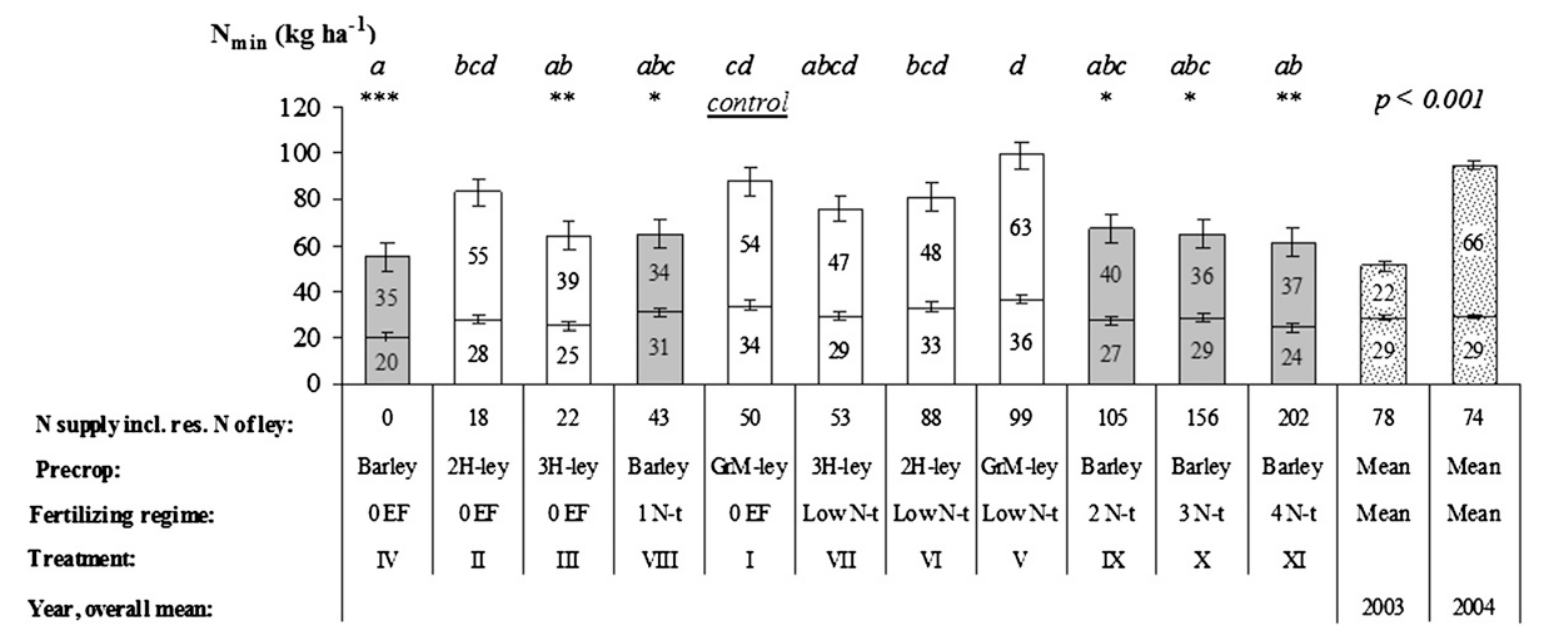

Fig. 2. Unused soil mineral nitrogen $(\mathrm{N})\left(\mathrm{N}_{\mathrm{min}}\right)$ at harvest of red beets as average for 2003 and 2004 . Lower part of columns $=0$ - to 60 -cm layer, the upper part $=60$ to $90 \mathrm{~cm}$. $\mathrm{N}$ supply $=\mathrm{NH}_{4}-\mathrm{N}$ with effluent + residual $\mathrm{N}$ of ley, in which residual $\mathrm{N}$ of ley corresponds to increase of $\mathrm{N}$ uptake in plants and $\mathrm{N}_{\min }$ at harvest of red beets after ley compared with in red beets after barley (see Eq. 4). Abbreviations for pre-crops: $2 \mathrm{H}-\mathrm{ley}$ and $3 \mathrm{H}-\mathrm{ley}=$ ley for biogas production harvested two or three times. Abbreviations for fertilizing regimes: $0 \mathrm{EF}=$ without addition of effluent, $1,2,3$, and $4 \mathrm{~N}$ - $\mathrm{t}=$ fertilization to red beets according to increasing $\mathrm{N}$ targets were $1 \mathrm{~N}$-t is the treatment with the lowest $\mathrm{N}$-target and $4 \mathrm{~N}$-t with the highest. Low N-t is used for grass-clover leys in which the $\mathrm{N}$-target was the same as in Treatment VIII in 2003 and as in Treatment IX in 2004. Asterisks show significant difference to the control, for $\mathrm{N}_{\min } 0$ to $90 \mathrm{~cm}$ according to Dunnett's test in a one-factorial analysis: ${ }^{*} P<0.05 ; * * P<0.01 ; * * * P<0.001$. Different letters show statistically differences, for $\mathrm{N}_{\min } 0$ to $90 \mathrm{~cm}$, at $P<0.05$ according to Tukey's $t$ test. $P$ value refers to differences between years. Error bars show SE of the mean for treatments: the upper for the layer 0 to $90 \mathrm{~cm}(\mathrm{n}=8 ; 4$ replicates and 2 years). 
of how to prevent leaching may be the most important factor, although organic BG systems offer opportunities to reduce $\mathrm{N}$ leaching. This implies a need for fall-growing crops such as catch crops (Dabney et al., 2001; Möller et al., 2008b), e.g., after the barley and after the red beets in crop Sequence C. However, the need for recommendations for preventing leaching may be as relevant for BG systems as for GrM systems (Shepherd and Chambers, 2007).

In the long-term perspective, slow release of organic $\mathrm{N}$ from effluent applied regularly in the crop rotation will increase soil fertility and $\mathrm{N}$ mineralization and leaching. Ross et al. (1989) reported more $\mathrm{N}_{\min }$ and increased $\mathrm{N}$ mineralization potential after 6 years of fertilization with effluent from biodigested crops than when only mineral fertilizer was used, although the total amount of applied N was similar. This suggests that the use efficiency of $\mathrm{N}$ from ley and red beet foliage will increase in the long term along with the risk of leaching as part of the $\mathrm{N}$ mineralization occurs also in the winter. However, Ross et al. (1989) compared a BG system with a mineral fertilizer system. The long-term effect on $\mathrm{N}$ mineralization in a BG system and a GM system may not differ.

We determined $\mathrm{N}_{\text {min }}$ immediately after harvest of red beets. For estimating the risk for $\mathrm{N}$ leaching, it would have been more advantageous to measure again in the first half of October (normally before $\mathrm{N}$ leaching starts) to see if fall mineralization from ley pre-crops had increased differences between effluent fertilized red beets after barley and red beets after ley pre-crops. However, dynamics for net $\mathrm{N}$ mineralization in the field experiment presented in Figure 1 in Gunnarsson et al. (2008) indicate that apparent net $\mathrm{N}$ mineralization of the ley pre-crops had already reached its peak in the end of June. This can be understood considering that the main biomass in the ley was white clover, which is known to give rise to fast $\mathrm{N}$ mineralization (Kirchmann and Marstorp, 1991).

\section{Conclusions}

The hypothesis that the net inorganic $\mathrm{N}$ equivalents and the marketable red beet yields in the BG crop sequences would increase without jeopardizing red beet quality compared with the GrM crop sequence tested was confirmed for the BG system with crop Sequence $\mathrm{C}$, where red beets followed spring barley. However, for Sequence B, where red beets followed harvested ley, the amount of net inorganic $\mathrm{N}$ equivalents did not increase, probably as a result of factors other than $\mathrm{N}$ limiting plant growth. An explanation should be sought for the low yield response for effluent in red beets after harvested ley.

When effluent was applied to red beets after barley in the BG system, the amount of unused $\mathrm{N}_{\text {min }}$ at harvest was smaller than after red beets after green manure and not fertilized with effluent. This indicates a potential for reduced risk of $\mathrm{N}$ leaching in $\mathrm{BG}$ systems compared with GM systems, although the risk may depend on several other factors, e.g., how the increased $\mathrm{N}$ fertilization effect is used in the whole crop rotation.

The need for efficient methanogenic activity and a high degree of digestion of potentially digestible $\mathrm{C}$ in the biodigestor, and thereby a high $\mathrm{NH}_{4}-\mathrm{N}$ :total $\mathrm{N}$ ratio, should not be underestimated when discussing biodigestion as a tool for improving the $\mathrm{N}$ effect of green manure ley and other crop materials.

The results reported here refer to red beet rows not damaged by wheel pressure during effluent spreading. Practical possibilities to spread the relatively large amount of effluent needed for red beets without damaging the soil or crop must be considered when introducing the BG technique on a farm scale.

\section{Literature Cited}

Alexandersson, H. and C. Eggertsson Karlström. 2001. Temperaturen och nederbörden i Sverige 1961-90. Referensnormaler. 2nd Ed. SMHI Meteorologi 99. SMHI (Swedish Meteorol. and Hydrological Inst.), Norrköping, Sweden.

Båth, B. and S. Elfstrand. 2008. Use of red cloverbased green manure in leek cultivation. Biol. Agric. Hort. 25:269-286.

Björnsson, L., M. Murto, and B. Mattiasson. 2000. Evaluation of parameters for monitoring an anaerobic co-digestion process. Appl. Microbiol. Biotechnol. 54:844-849.

Bonanomi, G., V. Antignani, C. Pane, and E. Scala. 2007. Suppression of soilborne fungal diseases with organic amendments. J. Plant Pathol. 89: 311-324.

Brewster, A.J.L. and A. Sutherland. 1993. The rapid determination in controlled environments of parameters for predicting seedling growth rates in natural conditions. Ann. Appl. Biol. 122: 123-133.

Bushwell, A.M. and H.F. Mueller. 1952. Mechanisms of methane fermentation. Ind. Eng. Chem. 44:550-552.

Campino, I. 1982. The effects of superphosphate and potassium fertilizer and salts on the nitrogen mineralization of incubated meadow soil. Fert. Res. 3:325-336.

Christiansen, J.S., K. Thorup-Kristensen, and H.L. Kristensen. 2006. Root development of beetroot, sweet corn and celeriac, and soil $\mathrm{N}$ content after incorporation of green manure. J. Hort. Sci. Biotechnol. 81:831-838.

Dabney, S.M., J.A. Delgado, and D.W. Reeves. 2001. Using winter cover crops to improve soil and water quality. Commun. Soil Sci. Plant Anal. 32:1221-1250.

Egnér, H., H. Riehm, and W.R. Domingo. 1960. Untersuchungen über die chemische Bodenanalyse als Grundlage für die Beurteilung des Nährstoffzustandes der Böden. II. Chemische Extraktionsmethoden zur Phosphor- und Kaliumbestimmung. Kungliga lantbrukshögskolans annaler 26:199-215. (The Annals of the Royal Agricultural College of Sweden; in German).

Granstedt, A. and G. L-Baeckström. 2000. Studies of the preceding crop effect of ley in ecological agriculture. Amer. J. Altern. Agr. 15:68-78.

Greenwood, D.J. 2001. Modeling N-response of field vegetable crops grown under diverse conditions with N_Able: A review. J. Plant Nutr. 24:1799-1815.

Greenwood, D.J., T.J. Cleaver, M.K. Turner, J. Hunt, K.B. Niendorf, and S.M.H. Loquens. 1980. Comparison of the effects of nitrogen fertilizer on the yield, nitrogen content and quality of 21 different vegetable and agricultural crops. J. Agr. Sci. 95:471-485.

Gunnarsson, A., F. Bengtsson, and S. Caspersen. 2010. Use efficiency of nitrogen from biodigested plant material by ryegrass. J. Plant Nutr. Soil Sci. 173:113-119.

Gunnarsson, A., B. Lindén, and U. Gertsson. 2008. Residual nitrogen effects in organically cultivated beetroot following a harvested/green manured grass-clover ley. J. Plant Nutr. 31: $1355-1381$.

Hansson, A.C. and R. Pettersson. 1989. Uptake and above-ground and below-ground allocation of soil mineral-N and fertilizer $-{ }^{15} \mathrm{~N}$ in a perennial grass ley (Festuca-Pratensis). J. Appl. Ecol. 26: 259-271.

Heinonen, R. 1985. Soil management and crop water supply. Dept. of Soil Sci., Swedish Univ. Agr. Sci., Uppsala, Sweden.

Janzen, H.H. and S.M. McGinn. 1991. Volatile loss of nitrogen during decomposition of legume green manure. Soil Biol. Biochem. 23:291-297.

Jensen, L.S., T. Salo, F. Palmason, T.A. Breland, T.M. Henriksen, B. Stenberg, A. Pedersen, C. Lundström, and M. Esala. 2005. Influence of biochemical quality on $\mathrm{C}$ and $\mathrm{N}$ mineralisation from a broad variety of plant materials in soil. Plant Soil 273:307-326.

Khanal, S.K. 2008. Microbiology and biochemistry of anaerobic biotechnology, chapter 2, p. 29-41, and Environmental factors, chapter 3, p. 43-63. In: Khanal, S.K. (ed.). Anaerobic biotechnology for bioenergy production - Principles and applications. Wiley-Blackwell, Singapore.

Kirchmann, H. and A. Lundvall. 1993. Relationship between $\mathrm{N}$-immobilization and volatile fattyacids in soil after application of pig and cattle slurry. Biol. Fertil. Soils 15:161-164.

Kirchmann, H. and H. Marstorp. 1991. Calculation of $\mathrm{N}$ mineralization from six green manure legumes under field conditions from autumn to spring. Acta Agricultura Scandinavia. 41:253-258.

Kolenbrander, G.J. 1974. Efficiency of organic manure in increasing soil organic matter content. Trans., 10th Intl. Congr. of Soil Sci., Moscow. 2:129-136.

Lindén, B. 2008. Efterverkan av olika förfrukter: Inverkan på stråsädesgrödors avkastning och kvävetillgång - en litteraturöversikt. Report 14, Division of precision agriculture, Dept. Soil Environ., Swedish Univ. of Agr. Sci., Skara, Sweden [in Swedish].

Loges, R., K. Ingwersen, A. Kaske, and F. Taube. 2000. Methodological aspects of determining nitrogen fixation of different forage legumes. In: Alfoldi, Lockeretz, and Niggli (eds.). Proc. 13th Int. IFOAM Sci. Conf.; Basel; 28-31 Aug. 2000. p. 92. vdf Hochschulverlag, Zürich, Switzerland

Möller, K. 2009. Influence of different manuring systems with and without biogas digestion on soil organic matter and nitrogen inputs, flows and budgets in organic cropping systems. Nutr. Cycl. Agroecosyst. 84:179-202.

Möller, K. and W. Stinner. 2009. Effects of different manuring systems with and without biogas digestion on soil mineral nitrogen content and on gaseous nitrogen losses (ammonia, nitrous oxides). Eur. J. Agron. 30:1-16.

Möller, K., W. Stinner, A. Deuker, and G. Leithold. 2008a. Effects of different manuring systems with and without biogas digestion on nitrogen cycle and crop yield in mixed organic dairy farming systems. Nutr. Cycl. Agroecosyst. 82:209-232.

Möller, K., W. Stinner, and G. Leithold. 2008b. Growth, composition, biological $\mathrm{N}_{2}$ fixation and nutrient uptake of a leguminous cover crop mixture and the effect of their removal on field 
nitrogen balances and nitrate leaching risk. Nutr. Cycl. Agroecosyst. 82:233-249.

Montgomery, D.C. 2001. Design and analysis of experiments. Wiley, New York, NY.

Myrbeck, A., T. Rydberg, M. Stenberg, and H. Aronsson. 2006. Inverkan av olika bearbetningstidpunkter på kvävemineraliseringen under vinterhalvåret och på kväveutlakningen i odlingssystem med och utan fånggröda. Slutrapport från försök 2000-2005. (Impact of times for soil tillage on $\mathrm{N}$ mineralisation during the winter and on $\mathrm{N}$ leaching in cropping systems with and without catch-crops. Report for trials from 2000-2005.) Report 110, Division of Soil Tillage, Dept. of Soil Sci., Swedish Univ. of Agric. Sci., Uppsala, Sweden [in Swedish with English summary].

NMKL. 1998. Metals. Determination by atomic absorption spectrophotometry after wet digestion in a microwave oven. Nordic Committee on Food Analysis, 161.

Nordberg, A., A. Jarvis, B. Stenberg, B. Mathisen, and B.H. Svensson. 2007. Anaerobic digestion of alfalfa silage with recirculation of process liquid. Bioresour. Technol. 98:104-111.

Pettersson, R., A.C. Hansson, O. Andrén, and E. Steen. 1986. Aboveground and belowground production and nitrogen uptake in lucerne (Medicago sativa). Swe. J. Agr. Res. 16:167-177.
Ross, D.J., K.R. Tate, T.W. Speir, D.J. Stewart, and A.E. Hewitt. 1989. Influence of biogas-digester effluent on crop growth and soil biochemical properties under rotational cropping. N. Z. J. Crop Hort. Sci. 17:77-87.

Santamaria, P. 2006. Nitrate in vegetables: Toxicity, content, intake and EC regulation. J. Sci. Food Agr. 86:10-17.

Shepherd, M. and B. Chambers. 2007. Managing nitrogen on the farm: The devil is in the detail. J. Sci. Food Agr. 87:558-568.

Sommer, S.G. and N.J. Hutchings. 2001. Ammonia emission from field applied manure and its reduction - Invited paper. Eur. J. Agron. 15:1-15.

Stinner, W., K. Möller, and G. Leithold. 2008. Effects of biogas digestion of clover/grass-leys, cover crops and crop residues on nitrogen cycle and crop yield in organic stockless farming systems. Eur. J. Agron. 29:125-134.

Svensson, K., M. Odlare, and M. Pell. 2004. The fertilizing effect of compost and biogas residues from source separated household waste. J. Agr. Sci. 142:461-467.

Svensson, M. 2005. The technology and economy of farm-scale, high-solids anaerobic digestion of plant biomass. Doctoral dissertation. Dept. of Biotechnology, Lund University. Lund, Sweden.

Takácsné Hájos, M., P. Simándi, and I. Posza. 1997. The effect of water supply and nitrogen doses on the pigment, nitrate- $\mathrm{N}$ and water soluble solids contents of table beet. Intl. J. Hort. Sci. 29:61-65 [Kertészeti Tudomány].

Thomsen, I.K. and B.T. Christensen. 1998. Cropping system and residue management effects on nitrate leaching and crop yields. Agr. Ecosyst. Environ. 68:73-84.

Torstensson, G., H. Aronsson, and L. Bergström 2006. Nutrient use efficiencies and leaching of organic and conventional cropping systems in Sweden. Agron. J. 98:603-615.

Uhte, R. 1990. Evaluation of experiments on nitrogen fertilization of vegetables by the linear response and plateau model. Gartenbauwissenschaft 55:247-251.

Webb, A.J., N. Patel, S. Loukogeorgakis, M. Okorie, Z. Aboud, S. Misra, R. Rashid, P. Miall, J. Deanfield, N. Benjamin, R. MacAllister, A.J. Hobbs, and A. Ahluwalia. 2008. Acute blood pressure lowering, vasoprotective, and antiplatelet properties of dietary nitrate via bioconversion to nitrite. Hypertension 51:784790.

Włodarczyk, T., J. Gliński, and U. Kotowska. 2004. $\mathrm{N}_{2} \mathrm{O}$ emission from mineral soils-Reviews. Res. Agr. Eng. 50:117-122.

Zauner, E. and U. Küntzel. 1986. Methane production from ensiled plant material. Biomass 10:207-223. 